Journal of Documentation 2019, accepted.

\title{
Knowledge creation and interaction in an R\&D project: the case of the Energy Weather Forecast
}

\author{
Anna Suorsa, University of Oulu, anna.suorsa@oulu.fi \\ Rauli Svento, University of Oulu, rauli.svento@oulu.fi \\ Anders V.Lindfors, Finnish Meteorological Institute, anders.lindfors@fmi.fi \\ Maija-Leena Huotari, University of Oulu, maija-leena.huotari@oulu.fi
}

\begin{abstract}
Purpose: The purpose of this study is to examine knowledge-creating interaction in developing an innovation in a multidisciplinary research community with hermeneutic phenomenology, to understand how previous experiences and future prospects shape the process and to examine the circumstances, which support or limit knowledge creation.

Design/methodology/approach: The approach of this study is phenomenological and the empirical case study has been conducted using ethnography. The data consist of field notes, videos, interviews and documents of a BCDC Energy consortium, developing Energy Weather Forecast (EWF) in a new type of research environment.

Findings: The findings indicate that the role of actual interactive events was crucial in the development of EWF. Hermeneutic approach illustrated, that the roots of that event were in the past experiences of the participants and the circumstances, which promoted the development of the innovation. However, the acknowledgement of the future prospects was crucial in finalizing the process. The role of a leader organizing the interaction and collaborative work was also substantial.
\end{abstract}

Practical implications: The results of this study could be used to plan and organize knowledge creation processes in organizations, especially in universities and research communities, striving to create multidisciplinary research environments and practices.

Originality/value: This study proposes a new approach based on hermeneutic phenomenology to examine it in a unified way, by focusing on the key aspects of elements affecting knowledge-creating interaction.

\section{Introduction}

In the past 20 years, the phenomenon of knowledge creation has become a major issue in the field of Knowledge Management (KM). Organizations need to constantly create new products and services and develop their own processes to survive in the changing environment. (Choo, 2016.) In addition, there are complex global and national problems, which require knowledge creation in multidisciplinary research communities, in collaboration with private and third sector organizations, and decision makers. Thus, the potential of universities and research consortia in the research and development (R\&D) work has been emphasized. (Migdadi, 2009; Hong et al., 2010.) The research on knowledge creation underlines the 
significance of interaction and collaboration in the creating process (Nonaka, 1994; Tsoukas, 2009). However, as sizes of research communities increase and participants are from various scientific disciplines, collaboration is challenging. In addition, the multidisciplinary research work is often conducted in multiorganizational environments, where people do not have possibilities to face-to-face interaction. Hence, the need for $\mathrm{KM}$ is clear, as knowledge creation processes need to be organized and managed to enable productive interaction (Auernhammer and Hall, 2014).

This study focuses on knowledge-creating interaction leading to an innovation in a research community. The empirical study was conducted ethnographically in the multidisciplinary and multi-organizational research community BCDC Energy, which aims at developing new solutions to smart energy markets related to production and use of renewable energy resources in Finland. Succeeding in this requires both flexibility and openness to different viewpoints and abilities to strategically manage the interactive process. Thus, it is essential to understand how the knowledge-creating process evolves from the first ideas to the implementation phase, where innovations are developed (see e.g. Popadiuk and Choo, 2006). Our case study focuses on the first innovation of the BCDC Energy, namely, the Energy Weather Forecast (EWF), which gives $24 \mathrm{~h}$ forecasts of wind and solar production for 200 locations in Finland. This innovation was a result of combining scientific research work to the strive to increase the societal impact of research by developing an application aimed for the wider public.

A vast amount of studies have been conducted to understand various, often quite contradictory factors in organizational context, human relations and human beings' own behavior influencing the process of knowledge creation (Auernhammer and Hall, 2014; Suorsa, 2015). However, there is a need to develop theoretical conceptualizations, which allow examining basic factors of knowledge creation through a unified framework (see Jashapara, 2004; 2005). Moreover, such longitudinal empirical studies are rare that focus on explicating and examining interaction in longer knowledge creation processes leading to the development of an innovation. In this study, we aim at fulfilling these research gaps by introducing a theoretically consistent conception of the premises of knowledge-creating interaction and using it to examine the process of knowledge creation in an empirical setting (c.f. Ragsdell, 2009). Our way to conceptualize and scrutinize knowledge creation is based on the phenomenological conceptions of human beings and interaction, which are based on the idea of human beings being inseparably connected to their environment (Heidegger, 1985; Gadamer, 1999a, 1999b). Our focus is on examining the dynamics of past and future, goal-centeredness and openness to new ideas, and dealing with similarities and differences in the knowledge creation process. These are based on a hermeneutic phenomenological understanding of the key factors in knowledge-creating interaction (Heidegger, 1985; Gadamer, 1999; see also Suorsa and Huotari, 2014; Suorsa 2015). This research setting allows examination of quite opposite requirements for knowledge-creating interaction simultaneously, without losing insight into the complexity of the phenomenon.

The research questions are:

1) How can the process of knowledge creation be conceptualized and examined with the hermeneutic phenomenological understanding of interaction and human beings?

2) How are the dimensions of a) temporality, that is, the past, present, and future of human beings; b) similarities and differences present in the experiences of the human beings and in the circumstances; and c) goal-centeredness and openness of the process and interaction, influencing the process of creating knowledge for the EWF?

Phenomenology has been used in the field of Library and Information Studies (LIS) by some scholars both as a way to understand the premises of the discipline and as a way to introduce methods for examining phenomena related to information and knowledge (e.g. Cornelius, 1996; Budd, 2001, 2005; Wilson, 2002a; Dalbello, 2005a, 2005b; Savolainen, 2007, 2008; Budd et al., 2010; Hultgren, 2013). The importance of interaction and communication in various information processes and practices has been acknowledged (Burns and Bossaller 2012; Robson and Robinson, 2013). In addition, there has been a growing interest on 
how to conceptualize and examine the experiences of information in the field of LIS (Latham, 2014, 2015; Bruce et al., 2014; Gorichanaz, 2015). Phenomenological philosophy has a place in this development, as it offers possibilities to understand human experience and the interactive nature of human beings. Therefore, our study adds this body of research and contributes to the epistemological and ontological development of the field by offering an approach to understand knowledge processes in organizations from a phenomenological point of view. Since the 1990s, the dominant position of the cognitive approach, which emphasizes an individual's inner processing of information and knowledge (Ingwersen, 1982; Belkin, 1990; see also Budd, 2011), has been moving towards approaches stressing human interaction with the context and each other (Vakkari, 2008; Capurro and Hjørland, 2003). This social nature of information and knowledge is acknowledged in research on information behavior and practices (Savolainen, 2007, 2008, 2009). Also in the research on organizational knowledge creation, more socio-constructivist and constructionist approaches have taken place. However, this has created problems when the cognitively oriented view of a human being is combined with hermeneutic ideas of interaction (Suorsa and Huotari, 2014; cf. Hjørland, 2004). Our study provides an alternative both to the cognitive approaches by acknowledging the interactive nature of human beings and to the socio-cognitive approaches, which are still attached to the idea of human beings being separable from the context (Värlander, 2008; see also Day, 2011).

\section{Theoretical background}

\subsection{Organizational knowledge creation and interaction}

$\mathrm{KM}$ as a field of research and as a conception is multidisciplinary in nature and involves the fields of LIS, Organizational Science, other Social Sciences, Educational Sciences, Information Systems Science, and Computer Science and Technology (Orzano et al., 2008; Jashapara, 2005). In the field of LIS, the relevance of the concept of KM has been debated, both from the science philosophical premises of the concepts of information and knowledge and thus questioning whether knowledge as such can be managed at all (Wilson, 2002b; Miller, 2002; see also Day, 2005; Yates-Mercer and Bawden, 2002). During the past decades, however, the value of the research and the viewpoints offered by the LIS scholars has been noted, and approaches integrating LIS with different fields have been developed (Jaspahara, 2004; 2005; WidénWulff and Ginman, 2004; Dalkir, 2011; Orzano et al., 2008; Evans et al, 2014). The interest of the LIS scholars has been to develop means to facilitate knowledge processes and manage knowledge assets in organizations (Evans et al, 2014, Shih-Wei and Mong-Young, 2004; Dalkir, 2011; Orzano et al., 2008). Therefore phenomena related to the management of knowledge on the macro level, such as life cycles of knowledge (Rowley, 2001; Dalkir, 2011; Evans et al., 2014) have been focused. However, also the human side of the KM has been examined during the past decades. Some insightful studies have been conducted to understand the work in different communities and contexts by using KM as a point of departure (e.g. Davenport, 2001; Orzano et al., 2008; Ragsdell, 2009; Känsäkoski, 2017). Especially the studies examining knowledge sharing (Hall, 2001; Widén-Wulff and Ginman, 2004; Widén-Wulff and Davenport, 2007; Ahmad and Widén, 2015), knowledge use (Savolainen, 2009) and information literacy in organizations (o'Farrill, 2010) come close to the themes examined in the studies of knowledge creation in the field of KM in general. However, in the field of LIS, studies examining knowledge creation and interaction are rare and focus more on the macro level (e.g. Shih-Wei and Mong-Young, 2004; Heinrich and Lim, 2005; Chua et al., 2006; Wang and Guan, 2005).

Overall, the phenomenon of $\mathrm{KM}$ can be viewed from different perspectives. One focuses on the management of information tools and resources and emphasizes the role of technology, whereas the other underlines human factors in knowledge processes and in developing productive conditions in organizations (Orzano et al., 2008). In this study, we concentrate on the latter view, which has until recently been examined especially in the fields of Organizational Science and Management. An extensive body of research on KM has explored knowledge-creating interaction in working communities (e.g. Alberts, 2007; Anand et al., 2010; Eliufoo, 2008; Martin-de-Castro et al., 2008; Olsen, 2009; see also Auernhammer and 
Hall, 2014). In these studies knowledge-creating processes are often conceptualized by utilizing Nonaka's model of organizational knowledge creation (Socialisation, Externalisation, Combination, Internalisation, SECI-model), which is based on the notion of tacit and explicit knowledge as convertible in nature (Nonaka, 1994; Nonaka and Takeuchi, 1995). Research has thus concentrated on identifying the types of knowledge and knowledge flows in different contexts on a macro level (e.g. Anand et al., 2010; van Helden et al., 2010; Ramírez et al., 2012). However, since the 1990s, more interest has been paid to the event of knowing and interpersonal relationships in working communities, focusing on the micro level interaction and collaboration needed in knowledge creation (Cook and Brown, 1999; Orlikowski, 2002; Küpers, 2005; see also McInerney, 2002). In the field of LIS, this is related to a wider development, where the social and contextual aspects of knowledge processes have been studied increasingly studies, and the importance of collaboration and context have been acknowledged (see e.g. Ingwersen and Jarvelin 2005, Talja et al. 2005, Hansen and Jarvelin 2005, Savolainen 2009).

Scholars examining knowledge creation are quite unified in the view that interaction is at the center of every knowledge-creating event (e.g. Cook and Brown, 1999; Morner and von Krogh, 2009; Tsoukas, 2009; Auernhammer and Hall, 2014). There is also consensus on the notion that during interaction people share their experiences and create new knowledge based on their previous experiences (Cook and Brown, 1999; Tsoukas, 2009; Suorsa, 2015). Information gained from one person always changes, as another person interprets it from his or her own perspective in a certain situation (Cook and Brown, 1999). In addition, it is acknowledged that knowledge creation always requires some kind of a new element that changes the existing state of affairs.

According to a recent study (Suorsa, 2015), the research of knowledge-creating interaction has concentrated on describing the optimal circumstances and atmosphere in workplaces, the relationships between the people in working communities, and the individual's own capabilities and actions that support knowledge creation. The influence of the organizational culture to the possibilities of creating new knowledge has been acknowledged (Auernhammer and Hall, 2014; see also Widén-Wulff and Ginman, 2004). The ideal mode of the human relationships in the working community is described as trustful (Cross et al., 2001; Huotari and Iivonen, 2004; Bligh, et al., 2006), open (Mitchell et al., 2009), familiar (Chua, 2002; Adenfelt and Lagerström, 2006), and equal (Herman and Mitchell, 2010). This means that knowledge creation is enhanced in communities where people know each other and each other's ways of interacting, and are free to express their own ideas and feelings. This is crucial, as new knowledge always requires questioning one's previous knowledge and expressing that one does not know something. In addition, the diversity of the community, meaning people from different backgrounds, cultures, and organizations, increases the possibilities for knowledge creation (Mitchell et al., 2009; see also Ahmad and Widén, 2015). Diversity creates differences that produce unsettledness, which may be removed by creating new knowledge (Tsoukas, 2009). However, to achieve this, the relationships and atmosphere in the community are in a pivotal position. In addition, the behavior and actions of the individuals matter - the ideal mode of being in interaction is described as open and reflective, but also as critical. In other words, people recognizing their prejudices, routines, and ways of thinking, can distance themselves from the usual action and consciously choose another course of action. (Topp, 2000; Gourlay, 2006; Verdonchot, 2006; Tsoukas, 2009.) (See Suorsa 2015, 2017.) All in all, the factors enhancing knowledge-creating interaction are tightly connected to the practices of knowledge sharing in the organizations (e.g. Widén-Wulff and Davenport, 2007).

In the research on knowledge-creating interaction, the importance of human relationships is linked with the context. The role of the management in facilitating good conditions for knowledge creation has been emphasised (Richtnér and Åhlström, 2010; Auernhammer and Hall, 2014). Trust and equality are developed also on the organizational level and are dependent on the organizational management, which hence is responsible for giving opportunities to develop new ideas and collaborate. To be able to take risks that often are involved when stepping out from the familiar routines or questioning previous knowledge, the support from the management is needed (Auernhammer and Hall, 2014). Flexibility in time, personnel, top management control, and financial resources have a positive impact on knowledge creation (Richtnér and 
Åhlström, 2010), as they leave room for critical consideration of different perspectives (Mitchell et al., 2009). However, management also concerns the effectivity of the work in the organization (e.g. Nonaka and Toyama, 2007; Nonaka, Toyama and Hirata, 2008). Even if organizational slack is essential in creating circumstances for knowledge creation, also some amount of pressures to complete the work is needed (Richtnér and Åhlström, 2010; Richtnér et al., 2014). Management in the knowledge creation processes has mainly been conceptualized on structural terms, and not as a factor present in the actual event of knowledgecreating interaction (c.f. Aggerholm and Thomsen, 2015; Aggerholm and Asmuss, 2016).

\subsection{Hermeneutic phenomenological approach to understand the process of knowledge creation}

As outlined above, knowledge-creating interaction is described in quite dialectical terms: there is a need for a secure, trustful and familiar community, where people can openly express their uncertainties, but also a need for diversity in terms of interacting with unfamiliar people. Similarly, people should have some prior knowledge and experiences in order to be able to create something new, but they should also be able to critically and openly evaluate that knowledge to find new solutions. In addition, there is a need for open and free interaction and possibilities for communicating with each other, but also management is required. Furthermore, knowledge-creating interaction is often described in terms of being both an experience and an event. Thus, there is a need for an approach, which allows all of these factors to be examined through a unified framework, where the understanding of the nature of the phenomenon of interaction is in line with the understanding of the human beings (Day, 2011) and the methods used (see Tsoukas, 2009).

Recent studies indicate that the phenomenological idea of a human being can offer this kind of a starting point for the conceptualization and empirical examination of knowledge-creating interaction (Värlander, 2008; Suorsa, 2017; see also Küpers, 2005). Phenomenological understanding allows means to examine the context, people and interaction related to knowledge creation as a single system, as the phenomenological approach pursues questioning the idea of separable objects, subjects and contexts. This is based on the basic premises of phenomenology, namely the focus on examining phenomena, as they appear (Husserl, 1981; Moran, 2002). By starting from the phenomena, the world and human beings living in the world are to be described differently, which has implications of the conception of knowledge. The ambiguity of knowledge that can be reached is highlighted: all knowledge is actually based on what is perceived and is thus dependent on the perspective of the perceiver (Moran, 2002). Thus, the human beings and knowledge are connected to the time, place, and experiences. This has implications to the basic understanding of the starting points of all research on human beings, their actions and interaction. In the phenomenological description, the human being is primarily a being in the world, who is not to be separated as an individual, object, or subject. (Heidegger, 1985; Suorsa and Huotari, 2014.) This means, that our relationship to the other human beings is shaped by our understanding of ourselves (Heidegger, 1985; see also Merleau-Ponty, 2006). Therefore our being, actions and experiences cannot be conceptualized or examined as individually.

Temporality of being is another important conception, which allows understanding the event and experience of knowledge creation. Temporality means that while acting and interacting in a certain situation, both past experiences and future expectations shape the event, similarly as in the general premises of knowledge creation described above (c.f. Tsoukas, 2009; Cook and Brown, 1999). In the phenomenological conception, however, temporality is a premise for understanding all being in the world. This draws our attention to the fact, that human beings' knowledge processes and interaction are events happening in certain a time and place. Furthermore, it is emphasized that both elements of past and future constantly exist in the present moment, and thus the temporal levels are in a constant flux, also shaping each other. (Heidegger, 1985.) The phenomenological concept of a human being is shaped by the idea of an open and questionable future full of possibilities. Therefore, human beings can seize the moment and understand their own opportunities, shaped by their past experiences (Heidegger, 1985; see Suorsa and Huotari, 2014). Consequently, being fully present in the moment is crucial, as acknowledging the temporality of the being can make us understand the possibilities in the moment. 
Based on the phenomenological premises described above, we can also understand and investigate interaction as a hermeneutic circle, where a human being acts supported by the horizon of expectation created by his or her prior experiences. This horizon is constantly changing as events progress. Thus, in principle, the hermeneutic circle is movement in time, and this movement involves anticipation, correction, and the reassessment of expectations. These, in turn, form a unified conception of the whole. One has certain prejudices and intentions, which guide the understanding, and in the event of hermeneutic communication with another human being, one should first and foremost acknowledge those prejudices, and also be able to re-evaluate them (Gadamer, 1999a). Thus, the hermeneutic circle describes an interpersonal event of meaning creation and interpretation in a certain time and place, when a new, better explicated and understood position towards a certain thing or challenge is created (Gadamer, 1999a). However, it should be noted, that for Gadamer, hermeneutics is not to be understood as a method of interpreting texts or other people - instead, it explicates the way of human beings as capable of understanding (c.f. Dilthey, 1990; Schleiermacher, 1977). Hence, the hermeneutic circle offers us possibilities to understand the continuous and ever changing nature of interaction in knowledge processes.

The idea of hermeneutic interaction has been used to analyze knowledge-creating discussions as such and concentrating on the detailed analysis of the dialogues (see Suorsa, 2017; see also Tsoukas, 2009), but it also describes longer knowledge creation processes, where previous knowledge, as well as the goals of the process, need to be constantly re-evaluated. The phenomenological conceptions presented above provide means to examine the balance between having certain goals and intentions, but also openness for new interpretations in the process of knowledge creation. The temporal dimensions of past, present and future structure and shape the knowledge creation process and interaction. At the same time, understanding of balancing between similarities and differences in knowledge creation process is gained. Accordingly, a framework for examining knowledge creation, which takes organizational contexts, human relationships, and human's own behavior and actions into account, can be outlined (see Figure 1). 


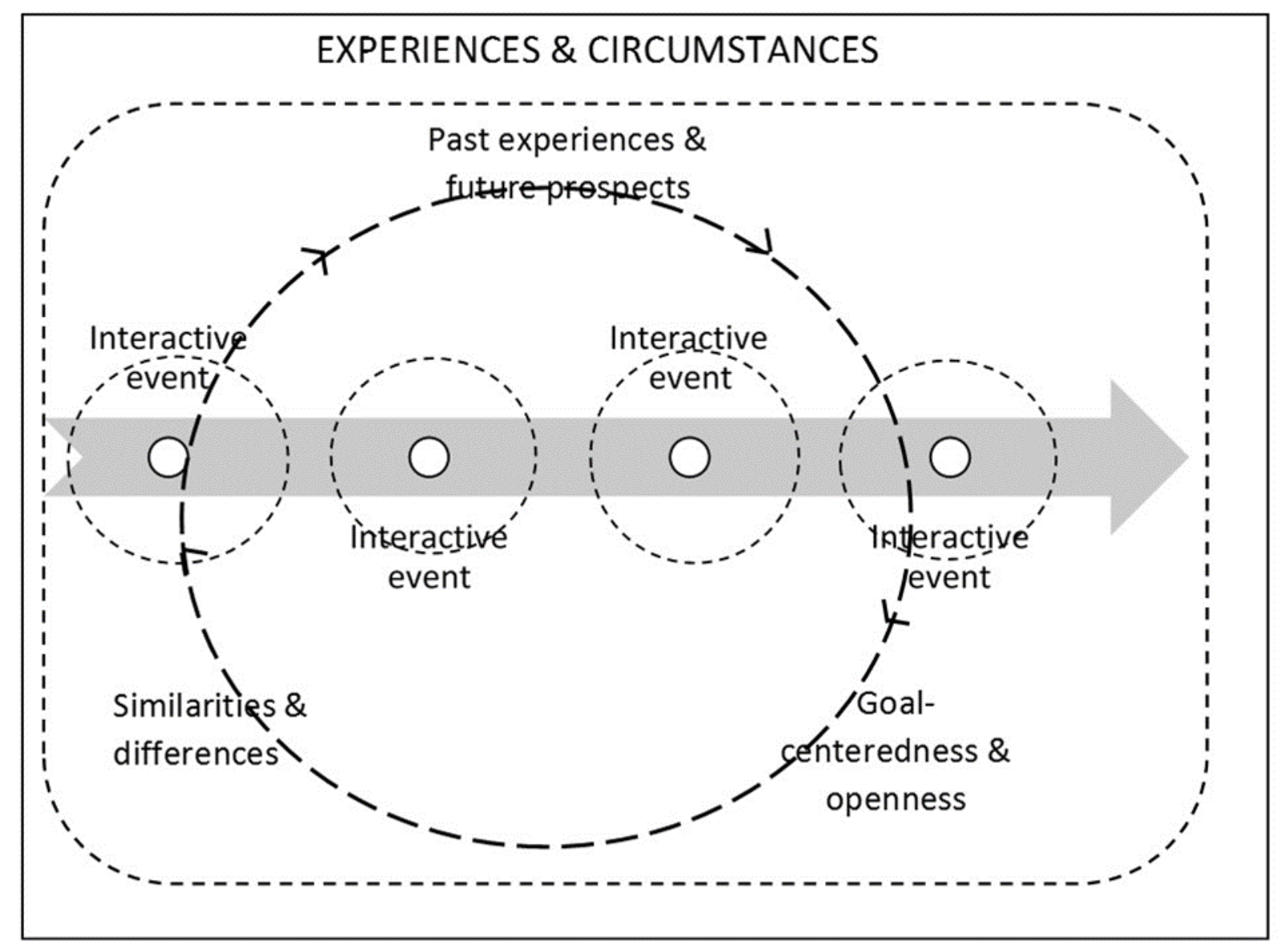

Figure 1: The framework of examining knowledge-creating interaction in this study.

The approach and the framework developed in this study contributes to the research of KM in the field of LIS by providing means to understand the human side of the knowledge creation process, deriving from the research conducted especially in the field of Organizational and Management Studies and phenomenological understanding of human beings and interaction. Underlying in the approaches developed in the field of LIS, has been an understanding of the organization as a system, where information and knowledge management are needed to support both individual and collaborative aims to succeed in different tasks (Jashapara 2004, 2005, 2007; Dalkir, 2011; Evans et al., 2014). However, the complexities present in a knowledge creation process in multi-organizational and multi-professional working communities are hard to capture by such models, which aim at capturing different knowledge processes and practices in organizations in general, or within an organization (Evans et al., 2014). Our study contributes to this body of knowledge by explicating the different levels and phases in the process of creating knowledge in a way, which allows understanding the collaborative nature of the knowledge processes in organizations. In addition, our approach highlights the dialectic and sometimes contradictory factors present in the process of creating knowledge (see also Auernhammer and Hall, 2014). In this, hermeneutic phenomenology offers us possibilities to examine the presence of quite opposite factors without reducing or simplifying the complexity of the phenomenon.

The factors emphasized in the research of knowledge creation become even more understandable in a phenomenological context, where the relevance of, for example, openness, familiarity, diversity, and historical experience is validated by the idea of being and hermeneutic interaction. The framework consequently includes the experiences of the human beings, the events of interaction, and the circumstances where the events happen. This framework is the basis for our empirical study. 


\section{Methods and data}

\subsection{Research environment: BCDC Energy}

The qualitative study was conducted among the researchers and collaborating partners working in a research consortium BCDC Energy ("Cloud Computing as an Enabler of Large Scale Variable Distributed Energy Solutions") in Finland. BCDC Energy is a multi-organizational and multi-professional community. The researchers are from two universities and Finnish Meteorological Institute (FMI), VATT Institute for Economic Research, and Finnish Environment Institute (SYKE). They form five research groups (RG) from the disciplines of Energy Economics, Computer Science Engineering, Meteorology, Information Systems Sciences, and Information Studies. There are over 40 members, located in two cities. Moreover, there are two strategic partners (SP), The Carbon Neutral Municipality Forum, and Finnish Clean Energy Association, and an Advisory Board (AB), consisting of members of 16 private companies. With the funding from the Academy of Finland's Strategic Research Council (SRC), the BCDC Energy consortium aims to develop a digital marketplace for clean energy trading in Finland. SRC is a new kind of financing instrument, and the crucial role of knowledge creating interaction and co-creation are outlined as follows: "SRC funds high-quality research that has great societal impact. The research should seek to find concrete solutions to grand challenges that require multidisciplinary approaches. An important element of such research is active collaboration between those who produce new knowledge and those who use it." (http://www.aka.fi/en/strategic-research-funding/src-in-brief/)

This case study investigates a process of creating the first collective innovation of BCDC, namely, the energy weather forecast (EWF). This application runs on the BCDC Energy's website converting "sunshine and wind into kilowatt hours for each location (in Finland) over the next 24 hours." (www.bcdcenergy.fi/energyweather) EWF was launched in June 2016, and since then, the public and actors in the field of energy have acknowledged it well. EWF had over 10,000 views in August 2018 (Google Analytics).

\subsection{Methods}

The qualitative ethnographic methods (Lopez and Willis, 2004) were deemed the most appropriate for this study (see Yin, 2009; Eisenhardt, 1989). The nature of the process of knowledge creation as intertwined in the everyday life of the working community justified this choice. In addition, ethnography as such relies more or less explicitly on phenomenology and does not conflict with the premises of the theoretical framework of this study (Maso, 2001; see also Jashapara, 2007; Ragsdell, 2009). The methods were also developed to match with the ideas of interpretive, empirical phenomenology. Hence, the emphasis was laid on the interactive nature of the experiences and temporality of being. (Lopez and Willis, 2004.) From the phenomenological point of view, the researchers cannot exclude their prior knowledge and understanding of the topic, and the role of the theoretical background guiding the research is recognized. However, it is important to make the preconceptions explicit and explain how they are used. (Lopez and Willis, 2004.) These notions guided the development of this study from forming the framework and operationalizing the examined elements to gathering and analyzing the data, by emphasizing the impact of the researchers in every phase of the study.

Therefore, the study was conducted in the light of an ethnographic approach (Smith, 2001; Maso, 2001), focusing on both the experiences of the community members and the interactive events of the community. Triangulation of qualitative methods and data was seen as relevant in order to get as much knowledge on the process as possible. The study had also features from auto-ethnography (e.g. Chang, 2008) as the authors were researchers in the BCDC community. The first author was a part of the community, assigned to examine interaction in the community right from the beginning, but was not involved in the development of EWF. The first author was responsible for gathering and analyzing the data, and she wrote the first version of the analysis, which was commented and complemented by the second and the third author, who were key players in the development of the EWF. The aim of this process was to gain as coherent view of 
the knowledge creation process as possible. Furthermore, this method was compatible with the phenomenological idea, that the researcher and the participants together create meanings (Laverty, 2003; Lopez and Willis, 2004; Moustakas, 1994).

\subsection{Data collection}

When collecting the data, the first author followed the work of the BCDC community from spring 2015 to winter 2017 as a part of the community. During this period, the community held several workshops, where the themes related to the EWF were discussed, presentations held and ideas developed further. In addition, various meetings were held related to the issues relevant for this study, such as developing the websites for the community with the advertising agency and meetings of the steering group of the community. By using different means, three data sets were gathered on the interactive events, the experiences of interaction, and the circumstances of the interaction.

Data set 1 consists of the observations and a field diary, and video recordings, collected in the meetings and the workshops of the community as a whole, and in the meetings held by only some of the community members (Table 1). The video recordings were usually conducted by using two video cameras, taping the actions from different angles. The first author was present in most of the meetings videotaping the events and simultaneously gathering observational data as a participant observer. She took notes by using timecoding, concentrating on what was happening and what was being said in the events, taking into account the conceptions highlighted in the theoretical framework. By this way, a field diary was written from the whole period. Each item of the data was given a code, by using a letter related to the form of the data and a number. Hence, video recordings are coded with V1-V20 and the field diary including observational data is coded with OD (see Table 1). These codes are used when referring to the data in next chapter.

Table 1: Data set 1 and the related codes used in this study.

\begin{tabular}{|l|l|l|}
\hline MATERIALS & AMOUNT & CODES \\
\hline $\begin{array}{l}\text { Observational data and field diary from the meetings, workshops and everyday } \\
\text { work in the community, written by the first author }\end{array}$ & 63 pages & OD \\
\hline $\begin{array}{l}\text { Video materials from the workshops of the BCDC community as a whole held } \\
\text { in Winter 2015 - Summer 2018 }\end{array}$ & $\begin{array}{l}\text { 9 events, total } \\
\text { duration 38 h 53 } \\
\text { min }\end{array}$ & V1-V9 \\
\hline $\begin{array}{l}\text { Video materials from the meetings held by some members of the BCDC } \\
\text { community in Winter 2015 - Summer 2018 (meetings between different RGs, } \\
\text { meetings with the partners and advertising agency, meetings of the steering } \\
\text { group of the community) }\end{array}$ & $\begin{array}{l}11 \text { meetings, total } \\
\text { duration } 17 \mathrm{~h} 32 \\
\text { min }\end{array}$ & V10-V20 \\
\hline \multicolumn{2}{|c|}{ In Total 56 h 25 min } \\
\hline
\end{tabular}

Data set 2 consists of the documents produced by the BCDC community (Table 2). They include agendas and memos from the meetings, e-mails, plans, reports, and presentations of the community, related to the development of EWF. The documents are coded with D1-D91 (see Table 2).

Table 2: Data set 2 and the related codes used in this study.

\begin{tabular}{|l|l|l|}
\hline THEMES OF THE DOCUMENTS & AMOUNT & CODES \\
\hline
\end{tabular}




\begin{tabular}{|l|l|l|}
\hline $\begin{array}{l}\text { Slides of the presentations held in the BCDC workshops on the themes related } \\
\text { to the EWF }\end{array}$ & $\begin{array}{l}5 \text { documents, 110 } \\
\text { pages }\end{array}$ & D1-D5 \\
\hline $\begin{array}{l}\text { Research plans of the BCDC Community (The original research plan in 2015, } \\
\text { Research plan for the second phase in 2017, Interaction Plan in 2015) }\end{array}$ & $\begin{array}{l}3 \text { documents, 22 } \\
\text { pages }\end{array}$ & D6-D8 \\
\hline $\begin{array}{l}\text { Official documents of the BCDC Community produced during the process of } \\
\text { developing the EWF (agendas and memos from the meetings of the } \\
\text { community, reports to the funder) }\end{array}$ & $\begin{array}{l}7 \text { documents, 31 } \\
\text { pages }\end{array}$ & D9-D15 \\
\hline $\begin{array}{l}\text { E-mail - discussions between the developers of the EWF during the knowledge } \\
\text { creation process in Winter 2015 - Summer 2016 }\end{array}$ & $\begin{array}{l}75 \text { documents, 75 } \\
\text { pages }\end{array}$ & D16-D91 \\
\hline \multicolumn{2}{|c|}{ In Total 238 pages } \\
\hline
\end{tabular}

Data set 3 consists of the semi-structured and recorded interviews of all the members of the BCDC community who were identified as being involved in the process of creating the EWF. One of the interviews was conducted via phone. The leader of the community was interviewed twice during the process. (See Table 3.) The interviewees were selected by discussing with the members of the community and analyzing the other data sets, to identify all the members of the BCDC community who were actively participating in the development of EWF. The interviews were conducted in 2017, after the EWF was launched. The interviews are coded with I1-I10 (see Table 3). In addition to the interviews, the leader of the community and one of the meteorologists wrote their own descriptions of the creation of the EWF and the information used in its development, as it was important to have also technically correct and detailed description of the aspects of the process. These are referred to by the codes S1 and S2.

Table 3: Data set 3 and the related codes used in this study.

\begin{tabular}{|l|l|l|l|}
\hline Members of the BCDC interviewed & Research Group (RG) & DURATION & CODES \\
\hline Leader of the consortium & Economists & $\begin{array}{l}44 \mathrm{~min}, 61 \\
\mathrm{~min}\end{array}$ & $\mathrm{I} 1, \mathrm{I} 2$ \\
\hline Informant & Economists & $78 \mathrm{~min}$ & $\mathrm{I} 3$ \\
\hline Informant & Meteorologists & $57 \mathrm{~min}$ & $\mathrm{I} 4$ \\
\hline Informant & Meteorologists & $50 \mathrm{~min}$ & $\mathrm{I} 5$ \\
\hline Informant & Meteorologists & $89 \mathrm{~min}$ & $\mathrm{I} 6$ \\
\hline Informant & Meteorologists & $120 \mathrm{~min}$ & $\mathrm{I} 7$ \\
\hline Informant & Information Systems Scientists & $46 \mathrm{~min}$ & I8 \\
\hline Informant & $\begin{array}{l}\text { Information and Communication } \\
\text { Studies }\end{array}$ & $79 \mathrm{~min}$ & I9 \\
\hline Informant & $\begin{array}{l}\text { Information and Communication } \\
\text { Studies }\end{array}$ & $101 \mathrm{~min}$ & I10 \\
\hline & \multicolumn{2}{|l|}{ In total 725 min } \\
\hline
\end{tabular}


In the interviews, the participants' background, aims concerning the work in BCDC, the meaning of interaction and interactive practices, and their conceptions of the development of EWF were dealt with in detail. Hence, the interviews were structured around five overlapping themes, outlined on the basis of the theoretical framework and the first author's experiences as an observer. However, the aim of the interviews was to openly discuss the experiences of the participants as suggested by Moustakas (1994).

\subsection{Analysis of the data}

The data analysis was a temporal process with three phases, guided by the ethnographic approach (Angrosino, 2011). At the first phase, the focus was placed on identifying relevant data related to the EWF from the vast amount of ethnographic data gathered in the BCDC Energy project as a whole. This was done by analyzing both Data sets 1 and 2 with a theory-guided approach. In Data set 1, the analysis concentrated on the phenomena that occurred frequently in the meetings observed and on the themes related to the EWF. The aim was to confirm and further elaborate the pre-understanding of the process of knowledge creation related to the EWF, and also to identify the moments when the EWF was mentioned or issues related to it discussed. The foci were both on the content of the speech and on the multimodal interaction of the events. In parallel with this, Data set 2 was analyzed, to comprehend the community's past experiences and future plans shaping the knowledge-creating process related to the EWF, as well as to examine the interactive process of developing EWF through these data. At this phase, the role of strategic management started to gain more emphasis than was assumed at the beginning of the study. Therefore, these analysis guided planning and conducting the interviews, with management and the role of the leader being the major themes.

In the second phase, the interviews were analyzed by applying qualitative content analysis, where the units of analysis were utterances, sentences, and clauses. Open coding was used to categorize the major themes. (Strauss and Corbin, 1990; Schreier, 2012.) The main categories found were interaction in the process, working tasks related to EWF, research, past experiences, goals, organizational circumstances, and strategic management.

In the third phase, all three data sets were analyzed concentrating on the process of creating the EWF through the lens provided by the framework (Figure 1). The themes focused were past experiences and previous knowledge, future prospects, goal-centeredness, openness of the process, similarities and differences. This was then examined in relation to the categories found in the second phase of the analysis, to gain understanding of the relationships between the nature of the knowledge-creating process as emerged from the data and the elements examined through the framework. An example of the coding process is illustrated in Table 4 below.

Table 4: Coding of the data sets in the third phase of the analysis.

\begin{tabular}{|l|l|l|l|}
\hline $\begin{array}{l}\text { Theme/Data } \\
\text { set }\end{array}$ & Examples from the data set 1 & $\begin{array}{l}\text { Examples from the data set } \\
\mathbf{2}\end{array}$ & $\begin{array}{l}\text { Examples from the data } \\
\text { set 3 }\end{array}$ \\
\hline $\begin{array}{l}\text { Past } \\
\text { experiences / } \\
\text { previous } \\
\text { knowledge }\end{array}$ & $\begin{array}{l}\text { "I am a professor of Economics in the } \\
\text { Business School, I've been here quite long, } \\
\text { my research interests are in environmental } \\
\text { economics, regional economics, something } \\
\text { I have done in health economics, but lately } \\
\text { in energy economics." (V10) }\end{array}$ & $\begin{array}{l}\text { "With respect to renewable power } \\
\text { generation, the FMI BC-DC-team } \\
\text { has successful record of projects } \\
\text { such as producing the Finnish Wind } \\
\text { Atlas" (D6) }\end{array}$ & $\begin{array}{l}\text { "So energy weather is this, that } \\
\text { when we have this meteorology } \\
\text { and weather and forecasting in } \\
\text { this house (FMI), so we those } \\
\text { skills and knowledge to it in a } \\
\text { way which is suitable for wind } \\
\text { and solar power" (I5) }\end{array}$ \\
\hline $\begin{array}{l}\text { Future } \\
\text { prospects }\end{array}$ & $\begin{array}{l}\text { "We go for a simple forecast. And we are } \\
\text { talking with the companies to gain data on } \\
\text { energy production to verify the } \\
\text { predictions" (V3) }\end{array}$ & $\begin{array}{l}\text { "We are trying to solve the data } \\
\text { issue - FMI does not have energy } \\
\text { production data - solar production } \\
\text { data could be possible to get from } \\
\text { XXX (A local energy company)" } \\
\text { (D10) }\end{array}$ & $\begin{array}{l}\text { "In the real world then, some for } \\
\text { could define its own systems } \\
\text { into it (EWF) and then create } \\
\text { forecasts for just those systems, } \\
\text { that is kind of a future goal" (I7) }\end{array}$ \\
\hline $\begin{array}{l}\text { Goal- } \\
\text { centeredness }\end{array}$ & $\begin{array}{l}\text { "We need modern ICT solutions, we need } \\
\text { new type of weather forecasts, and we aim } \\
\text { at combining these in cloud-based new } \\
\text { types of digital services, that can be used in } \\
\text { aggregating the, the different types of }\end{array}$ & $\begin{array}{l}\text { "Efficient management of demand to } \\
\text { correspond variable production } \\
\text { requires totally new 1) market } \\
\text { mechanisms and market participants, } \\
\text { 2) efficient transmission of real time }\end{array}$ & $\begin{array}{l}\text { just like this, that the world is } \\
\text { changing and there will be more } \\
\text { and more weather related energy } \\
\text { production and its good for us to }\end{array}$ \\
\hline
\end{tabular}




\begin{tabular}{|c|c|c|c|}
\hline & $\begin{array}{l}\text { activities that are possible in this new, new } \\
\text { world that is building up." (V1) }\end{array}$ & $\begin{array}{l}\text { information related e.g. to load, } \\
\text { production and weather forecasts } \\
\text { (wireless ICT) and 3) digital } \\
\text { services." (D6) }\end{array}$ & $\begin{array}{l}\text { transform our research so, that it } \\
\text { can answer the needs related to } \\
\text { that change." (I5) }\end{array}$ \\
\hline Openness & $\begin{array}{l}\text { Economist: "Very very important and } \\
\text { interesting question also, how to change the } \\
\text { the weather forecasts into energy forecasts } \\
\text { that is something that we definitely need to } \\
\text { look at." } \\
\text { Meteorologist: "I guess this is one, one } \\
\text { point we need to co-operate also it is } \\
\text { something, I'm, I'm not sure there, there } \\
\text { might be some knowledge gaps here, but } \\
\text { we need to identify then perhaps. (V1) }\end{array}$ & $\begin{array}{l}\text { "XXX (Member in the RG2) has } \\
\text { invited others to join and write } \\
\text { together, RG3 and RG4 have already } \\
\text { joined" (D10) }\end{array}$ & $\begin{array}{l}\text { "So in that time frame it was } \\
\text { revealed that actually XXX was } \\
\text { not really familiar with Python, } \\
\text { but he said that he can learn and } \\
\text { take care of it" (I2) }\end{array}$ \\
\hline Similarities & $\begin{array}{l}\text { Economist 1:" This is linked with the } \\
\text { knowledge they (RG3) are able to produce, } \\
\text { it should be converted effectively" } \\
\text { Economist 2: "to change it to the energy } \\
\text { potential" } \\
\text { Economist 1: "yeah, and knowledge related } \\
\text { to it should be effectively transmitted to the } \\
\text { system, and this is related to our work } \\
\text { (RG1), so that we can give the right signals } \\
\text { to the markets" } \\
\text { Economist 2: "and then RG4 has to do the } \\
\text { actual work, like what happens in the } \\
\text { service" (V14) }\end{array}$ & $\begin{array}{l}\text { "The main goal of this project is to } \\
\text { build a cloud computing based } \\
\text { market place of electricity trading } \\
\text { (CBES) where all of these above } \\
\text { mentioned issues (Tasks of all the } \\
\text { participating RG's combined) can be } \\
\text { combined." (D6) }\end{array}$ & $\begin{array}{l}\text { "Well I think this EWF is really } \\
\text { good, and it is in line with the } \\
\text { goals of our house (FMI)" (I5) }\end{array}$ \\
\hline Differences & $\begin{array}{l}\text { "And this is our consortium, five partners, } \\
\text { seven teams, I'm very, very happy about } \\
\text { this, bunch of very good people with a, } \\
\text { with high knowledge and top quality } \\
\text { research" (V1) }\end{array}$ & $\begin{array}{l}\text { "A problem: in the research plan we } \\
\text { do not have identified and written } \\
\text { down any clear goals, in chapter } 4 \\
\text { BCDC describes its research in } \\
\text { different RGs" (D11) }\end{array}$ & $\begin{array}{l}\text { "Well of course it is a limitation } \\
\text { of some kind, if we are } \\
\text { physically in different places } \\
\text { and don't see each other face-to- } \\
\text { face so often" (I7) }\end{array}$ \\
\hline
\end{tabular}

\section{Findings}

The results of our analysis of the knowledge creation process of the EWF can be reported on several levels, coming from our hermeneutic approach. Our analysis suggests, that the dimension of similarities and differences could be seen to describe the past, whereas the dimension of openness and goal-centeredness was linked with the future. Hence, the process of knowledge creation could be described as a flow of continuous events of interaction in the present moment, where the past and future were shaping the development of the EWF. In this chapter, we first describe how the eventness of the knowledge creation as a phenomenon could be used to understand the development process of the EWF. Second, we examine, how the knowledge needed for EWF was rooted in the previous knowledge and historical experiences of the participants. Finally, we examine the knowledge process in terms of constantly moving towards the future prospects, and describe, how that process is facilitated by a strategic management.

\subsection{Circumstances creating possibilities for knowledge-creating interaction}

The eventness of the phenomenon as emphasised by the phenomenological understanding of knowledgecreating interaction (Heidegger, 1985; Värlander, 2008) is evident when the EWF was created. There was enough time and opportunities for interaction in the community's work, which gave space for creating the EWF.

The process of creating and developing the EWF happened as a series of events, leading from the first ideas to the final publication of the application. The idea of the EWF was created during an informal discussion in the first get-together dinner between the researchers of Energy Economics, Meteorology, and Information and Communication Studies, together with some members of the Advisory Board (I1, D10). This dinner was held in connection with the kickoff meeting of the BCDC community in December 2015 (D12). The creation of EWF was not planned in the BCDC community's agenda before, but after the enthusiastic discussion (I1, I4, I10), the leader of the community (LoC) started proceeding with the idea mainly by e- 
mails with the Meteorologists, presenting the idea and negotiating about the details of the content (D16D28). The communication specialist from the Information and Communication Studies' research group (RG) and the advertising agency were also involved in discussions. It was decided, that the Meteorologists would develop a model for the EWF (I5). For implementing the application to the BCDC Energy website, there was a need for expertise in coding (D29-D45). Finally, a member of the Information Systems scientists' RG ended up developing the code in interaction with the Meteorologist, who occasionally tested the solution (D46-D60). When the EWF was implemented on the website, the roles of the advertising agency and the members of the Information and Communication Studies were emphasized and interaction via e-mail was intense (D61-D85). The EWF was launched in June 2016 (D88).

As such, the creation of the EWF was unexpected. However, the analysis of the data related to the past experiences of the community members and interaction in the events before the creation of the EWF, indicates that there were several preceding phases and simultaneous processes promoting the EWF, and the work evolved hermeneutically, drawing from the past and anticipating the future. According to the analysis, the circumstances necessitated by the funding body of the BCDC Energy consortium, the SRC, were an important factor supporting the development of the EWF, as the SRC emphasizes both the interactive cocreation between different scientific disciplines and collaborating partners, and communication about the research and its results to the wider public. Hence, the BCDC community was set up as a multidisciplinary one, and besides the pursuit of creating new research results, the work was oriented towards communicating about the research effectively (D6, D8). Therefore, a communication specialist was appointed as a member of the Information and Communication Studies' RG. In addition, during the creation of the idea of the EWF, the leaders and the Information and Communication Studies' RG were developing the community's website together with the advertising agency (V11-V13, I1, I2, I10). This had an impact on the development of the content of the idea of the EWF and its form as an ICT-application available on the community's new website.

The work in BCDC was organized based on the notions of the importance of interaction and flexible circumstances. This was emphasized in the research plan (D6), and also by the Information and Communication Studies' RG in the meetings with the leaders of the community held before the kickoff meeting (V14, OD). Flexibility was also connected to the phase of the work in the community, which was still in its infancy, searching for new ideas and concrete goals, and discussing continuously about the SRC's goals of communicating and popularizing science, as SRC was a new funding instrument for all members of the community (I1, V10, V14). The kickoff event, where the idea of EWF was created, was planned in a manner that promoted informal discussions by encouraging encounters between different RGs, the members of AB, and the Strategic Partners (D8, V14). The need to collaborate was combined both with the scientific aims and the aims of having an impact on society in the opening words of the leader of the consortium: "We need modern ICT solutions, we need new type of weather forecasts, and we aim at combining these in cloud-based new types of digital services, that can be used in aggregating the, the different types of activities that are possible in this new, new world that is building up. And we also aim at building an active community for (...) smart energy users. We have five WPs (...), to be able to end in what we want to do, this is a genuinely interdisciplinary project and we need input from every WP and every team. So we really need to collaborate and interact." (V1) Thus, it was clear to all that interaction over the borders of the RGs, AB and SCs was crucial and promoted, and the eventness of the knowledge creation highlighted. Thus, the community had plans and visions, but the actual implementation of ideas to a functioning solution remained unclear until the community members were able to discuss about them informally (OD). This process is illustrated in Figure 2. 


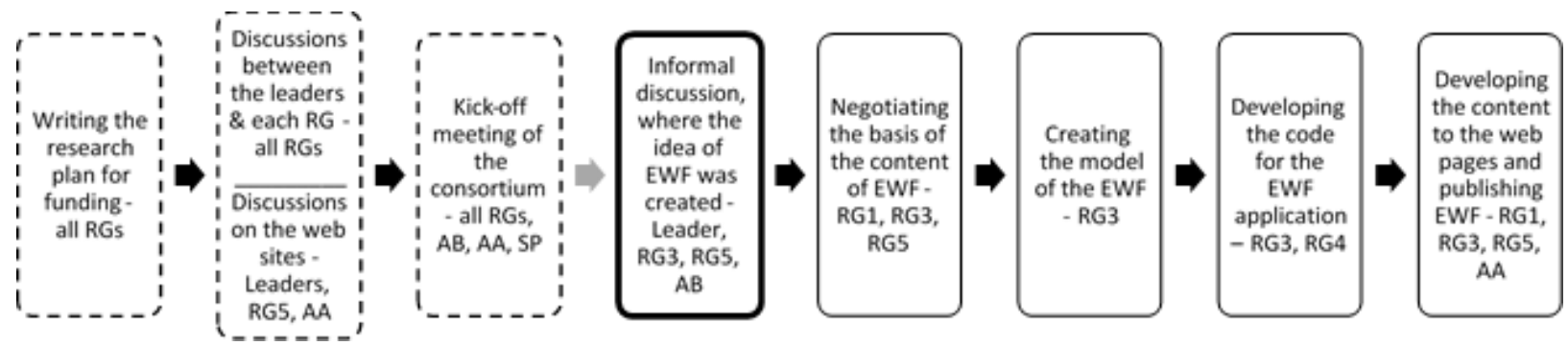

Figure 2: The knowledge creation process of developing the EWF as the interactive phases of the events from the idea through organizing the work.

\subsection{Similarities and differences in past experiences shaping the encounters}

In the core of creating something new, is the notion of previous knowledge being critically reviewed, questioned, and re-organized when encountering something new. In that process, the similarities and differences of the people involved in the process affect the nature of the interactive process, as well as the final product. (Suorsa, 2017.) Examining the development of the EWF as a hermeneutic process draws the focus on the balancing between having a common ground in terms of knowledge, to be able to understand each other, and encountering something strange or new, which need to be connected to the previous knowledge. These kinds of events can either result in developing a more correct understanding of the issue at hand, or cumulating to develop totally new combinations and concepts (see also Tsoukas, 2009). In developing the EWF, the diversity in the past experiences of the community members was both supporting and prohibiting the knowledge-creating process. The starting points were promising but challenging, as the community was formed for conducting the BCDC project as outlined in the funding application for the SRC along with the research plan. Thus most of the community members did not know each other beforehand. The community was located in two cities and involved many organizations, which did not allow face-toface contacts between LoC and the key developers of the EWF on a daily basis (I7). This was partly taken care of by acquiring two virtual platforms for sharing knowledge and information (OD). However, working in different organizations and disciplines meant, that the community members did not have a shared history of working together in practice.

Overall, the role of differences in scientific knowledge was significant in the development of the EWF. The diversity of the multidisciplinary community was manifest in its knowledge-base and described in detail already in the research plan, which also included descriptions of the previous knowledge and experiences of the participants related to the themes of the $\operatorname{EWF}(\mathrm{D} 6, \mathrm{D} 8)$. Energy forecasting as such was not mentioned in those plans, and was not in the focus of the Meteorologists: "...in our part of the plan we concentrated more on the research, like how to improve (...) the forecasting models." (I5) However, the phenomenon of energy weather was familiar to the meteorologists, and they had a background in creating such models. This was essential in creating the content of the EWF. Besides the knowledge on forecasting energy weather, the development of the EWF required knowledge on energy markets offered by the Economists, who had been doing research on "sustainable energy economics such as the effects of real-time pricing on long run efficient investments, efficient use of renewable energy and promotion market access for renewable intermittent energy" (D6).

To be able to create the idea of the EWF, required understanding of the importance of having a solution to the problem caused by the variability of the energy production with the renewables. The economic understanding of this was based on the previous knowledge on energy markets and the need for flexibility: "Traditionally demand response has been targeted on cutting the peaks in the demand so that most expensive and emitting stations need not be started up. But demand response is a more general concept than just peak sneaking. It also means the possibility to adjust consumption based on the supply from renewables." (S1) Thus, the previous scientific knowledge underlined the need to create an application, 
which in a concrete manner illustrated the connection between renewable energy production and weather conditions. This multidisciplinary understanding of the markets and weather conditions and forecasting was combined with the understanding of the consumers and producers of energy, supported also by the members of the AB: "But then we had the idea that also the general public needs these forecasts. Households to plan their own electricity usage at home and at holiday resorts. Wind farms need these forecasts to plan their bids into the day-ahead market." (S1) This was promoted by the new circumstances emphasizing the public engagement by the funding body, SRC (I2).

Accordingly, the differences in the knowledge bases of the Economists and the Meteorologists brought together resulted in creating the EWF. However, it should be highlighted that there was already much understanding of each other's disciplines, which was also manifested in the discussions of the community (V1, V3, V10) and in the research plan. Furthermore, there was an understanding that combining forecasts and information on energy markets was possible, based on the previous experiences of the Economists: "So I3, in her thesis, has these exact mathematical formulas to convert weather conditions into energy (...) so we knew we could undertake this because we had already conducted some related studies..." (I2) Even though the EWF was finally based on another model (D19, D22), it was important that the LoC had this understanding of the possibilities of making such an application (I2, I3, I9), as he launched the development of the EWF.

\subsection{Goal-centeredness and openness in the knowledge creation process}

\subsubsection{The hermeneutic process of re-evaluating the goals to succeed in developing the $E W F$}

The temporal nature of the human beings is seen in our ability to constantly derive from the past and anticipate the future, as we act and interact within our surroundings (Heidegger, 1985). The creation of new knowledge, hence, can be seen as constantly evaluating and re-evaluating the anticipated future and hence the knowledge needed for reaching the goals (Gadamer, 1999b). In the background of the EWF, was the understanding of the goals of the BCDC community and the ability to see how the EWF could enhance the community to reach those goals $(\mathrm{V} 14, \mathrm{~V} 2)$. In the research plan, the main aim of the community was formulated in a way that implicated the development of the EWF: "Our aim in this project is to find solutions that materialize the full potential of variable energy sources in cost minimizing economically efficient ways. (...) Efficient management of demand to correspond variable production requires totally new 1) market mechanisms and market participants, 2) efficient transmission of real time information related e.g. to load, production and weather forecasts (wireless ICT) and 3) digital services. The main goal of this project is to build a cloud computing based marketplace of electricity trading (CBES) where all of these above mentioned issues can be combined." (D6) Hence, there was a goal to collaborate for combining the knowledge from each scientific discipline related to forecasting and the energy system. However, the research plan was written in such a manner that highlighted the division into the different scientific disciplines based on their separate aims (D6). As a whole, the findings indicate that in the plan, as well as in the discussions of the community's meetings, there were many crucial goals to be reached requiring collaboration and new solutions, for example, developing smart grids and cloud-computing services (D6, V10, V1). Thus, it was noteworthy, that the first actual solution was developed in the field of energy weather forecasting. Here, the role of the $\mathrm{LoC}$ was crucial in organizing the interaction and managing the work from one phase to next phase (D16-D28).

\section{Setting the goal for the $\mathrm{EWF}$}

First outline for the goal in developing the EWF was sent in the first e-mail of the LoC when he presented the idea to the Meteorologists: "(The advertising agency) is working on a BCDC website and an idea came up in the kickoff related to that: we could place an energy forecast on the front page instead of a weather forecast. This would be actualized as something like this: when the website is opened, the local wind and 
solar forecast information are drawn and transformed into energy forecasts, and then combined with the NordPool Spot price and turned into euros." (D16) Thus, already at this stage, there was an understanding of how the work could progress and what could be the content, based on the previous knowledge of the participants, their abilities, and the data available. In addition, there was a goal of getting some content to the new website of the BCDC community (V1, V11, V19).

\section{Re-evaluation of the goals}

As the interactive process of developing the EWF was launched, the idea had to be sharpened by reevaluating the goals in order to be able to create a detailed model for the EWF and to implement the application to the BCDC's website. The first re-evaluation was connected to the scientific knowledge of forecasting energy weather, to answer the following questions: "What is the time frame for the forecasts? What is the geographical space to be used? What power volume to base our forecasts to? Do we attach monetary information to the application and the forecast volumes?" (S1) These were discussed mainly by e-mail between the Economists and the Meteorologists in a process supported by both group's deep understanding of the subject matter and the limitations of the circumstances (D16-D28). From the Economists' point of view: "The day-ahead market operates on an hourly time frame and the FMI weather forecasts are easy to adjust to this time frame. We soon decided to make 24 h day-ahead forecasts that would update every hour. The geographical solution easily turned out to be the network of FMI measurement stations around Finland (...). We decided to use a lower end for power volumes just not to exaggerate the possibilities. This in mind we ended up to a size of $2.5 \mathrm{~kW}$ for the panels and a corresponding wind power mill." (S1) The Meteorologists had a more detailed picture of the problem and its solution: "... (it) should be based on forecasted weather conditions of FMI's Numerical Weather Prediction models, and these weather conditions should be translated into energy output (in $k W h$ or $M W h$ ) instead of presenting meteorological parameters such as incident solar radiation or wind speed. Partly, these tools were already available at FMI, and partly, we needed to create something new." (S2)

Secondly, the goal of having monetary information in the model had to be re-evaluated: "However, based on our understanding of the economics of the power grid we decided to leave them out, (because) (...) the distribution prices are very different in various regions of Finland, and (...) the supply market has been liberalized to competition in Finland and there are very many suppliers in the market with very different types of contracts." (S1) Thus, even if the members understood that this kind of a solution would be informative to the consumers, they decided to leave it out (S1). These discussions took place both face-toface (I9, I10) and in e-mails between the LoC and Information and Communication Studies' RG, and they were related to the role of the funding body of the project, the SRC, and its goals (I2, I10).

In the end, the model of the EWF was developed based on the previous knowledge of the Meteorologists and FMI. The researchers had to find right ways to use the information available and make choices, which were on the one hand highly scientific, but had really practical implications connected to the users of the EWF: "(We decided to) 1) (use) wind energy tool created based on FMI's knowledge (wind atlas), 2) (use) solar energy tool created based on FMI's knowledge (solar radiation) and PV models presented in literature, 3) (use) technical specs: $2.5 \mathrm{kWp}$ wind turbine \& $2.5 \mathrm{kWp}$ solar PV installation, (...) 4) (use) FMI's open data (for easy creation of data stream and portable software) (...) we chose to use features readily available in the FMI open data: list of locations/cites in Finland according to ready-made list (and some locations in the very north added after a request from I10)." (S2) This phase included both face-toface interaction within the Meteorologists and e-mail discussions between the Meteorologists and the LoC (D16-D28, I1, I4, I5, I6, I7). Also the communication specialist of the Information and Communication Studies' RG was involved, to assure that the content was properly targeted to the wider public (I2, I5, I9, I10).

Another theme of forming and re-evaluating goals was linked with the development of the technical solution of coding the EWF: “...the original idea was that the people at (the advertising agency) (...) can do it, (...) then it turned out that (the person working with us in the advertising agency) is not a Python expert either, 
and on the server this kind of service can only be run on Python." (I2) This created a phase of intense interaction mainly by e-mail, as the members strived to find out who could do the work in practice. (I2, I5, OD, D29-D45.) Finally, one of the Information Systems Scientists ended up creating the code (I2). The Information Systems Scientist was familiar with Python as such, but he had to learn how to code the EWF using data from HIRLAM (I8). In this phase, there could have been more support from the Computer Science Engineers, as one of them was an expert on using Python, but the LoC did not know that, and that RG was not included in the discussions: "... but of course I should have asked the engineers over here (in Oulu), because then (one of the Computer Science Engineers) programmed everything on Python, and it would have been more convenient... "(I2). Thus, the lack of interaction outside the key group developing the EWF affected the process, as the LoC did not totally know each other's past experiences and expertise.

\subsubsection{Re-evaluation of the goals in relation to the strategic management of the process}

The analysis of the data sets reveals, that the above described knowledge creation process, which resulted in a successful new application, was a combination of carefully planned work in the research community, lucky coincidences, right circumstances, and a decent amount of interaction in every phase of the development. The analysis of the interaction and communication of the community members highlights the role of the leader of the consortium as an organizer of the interaction and the work so, that the process could move from one phase to next phase. In this role, he send mostly e-mails to the group of researchers and the staff of the advertising agency, delegating the work and solving problems especially in the situations, when the work had to proceed. The plans and goals of the community shaped this work, which could be seen as strategic management, heading for reaching both the scientific goals of the community (D6) and for creating an innovation aimed at the wider public. However, as the whole process and all the participants' actions and experiences were examined, we could see, that all the participants were involved in this task, by making compromises and evaluating what could be possible. Crucial in this were the discussions and presentations in the community's workshops on the premises of the work and goals set also by the SRC (V1, OD).

The analysis suggests that the openness to new ideas and ways of working affected the development of the EWF and was connected to the ability to also manage the process by making timely decisions. As the community members planned the launching of the EWF application, there was a need to discuss about what could be stated on the website about the EWF, and the members of the community were also able to accept the limits of the application. Sometimes there were negotiations considering the possibilities: "I10 would have absolutely wanted the forecast to show how many euros it means, (...) we didn't want it (...) but then, we put in a link to these examples on different electric companies websites (...)." (I2) For the researchers, it was important to emphasize that the application was not a result of detailed research: "In my opinion, it should be clearly brought forward (in the communication) that it really is a showcase (...) and as such should not be marketed as being the best there is, because it's not and it's more of a conversation, in my opinion." (I7) However, the EWF was seen as a first step to reach the final, strategic goal of the community: "that it is, like, sort of a baseline for everything when we start building it forward." (I7) Hence, creating the EWF supported the overall goals of the BCDC, as it enabled calculating energy production based on meteorological information. This was not only an important step toward a well-functioning cloud energy broker service, but also an important tool that supports solving various research questions on, for example, how renewable energy can be utilized in the best possible way in the future energy system (D6, D7, D10). In addition, the EWF functioned as a tool to enhance understanding of the scientific goals of the community in the discussions within the BCDC community after its development (e.g. V2, V3, V4, V7).

Another important theme, which required strategic management of the decisions, was the complexity of the forecasting of energy weather. Of the various options of the parameters, the simplicity was chosen: "There was actually some conversation about it when we were making it, that whether we should add in some open blocks or not, maybe it's good that it is the way it is, that we didn't even try, because it would have been 
some kind of a compromise in any case, and if we tried to make it as wonderful as possible, we would probably have to be updating it." (I7) In that sense, the openness in setting the goals and aims was seen as one of the most important features of the process, as the solution was created even if it was clear that it could not be as complex as it should be, if it would take into account all the research knowledge on the topic. Thus, the ability to adjust the goals to the circumstances was crucial in finalizing the EWF. It was evident, that there was a need to compromise for developing a solution that was good enough in the limits of time and complexity: “... that we didn't make it (EWF) too complicated, that we didn't set the bar too high right there in the beginning because then it could easily take like two years to develop. (...) And by doing this I think we have managed to gain good visibility and we have found parties who are interested in this topic." (I5) Here the understanding of the goals in communication and popularization were present, as well as the fact that research and implementation may have quite different goals. Hence, our analysis suggests, that even if the role of the LoC was crucial in the moments of doing some strategic decisions, also the other members of the community were participating in the strategic management with their actions and contribution to the development of the EWF.

\section{Discussion}

In this study, we have examined the development of the EWF with our phenomenological approach on knowledge creation. The research questions were: 1) How can the process of knowledge creation be conceptualized and examined with hermeneutic phenomenological understanding of interaction and human beings, and 2) How are the dimensions of a) temporality, that is, the past, present, and future of human beings; b) similarities and differences present in the experiences of the human beings and in the circumstances; and c) goal-centeredness and openness of the process and interaction, influencing the process of creating knowledge for EWF.

\section{The hermeneutic phenomenological approach}

Based on the notions of the temporality of the human beings (Heidegger, 1985) and hermeneutic circle as a basis for understanding interaction (Gadamer, 1999a, 1999b), the knowledge creation process in the development of the EWF could be described as a hermeneutic process of interactive events, which contains moments of open and free interaction. However, this process contains also more organized phases of progressing towards the goals set for the R\&D work. The organized phases were related to the decisions and actions of the leader of the community and other community members central in the development process. This finding suggests, that strategic management of interaction was evident in the process and also achieved collaboratively. In addition, the interactive events of the process were shaped by the past events and experiences, as well as the anticipation of the future, changing in the course of time. This process could be seen as a hermeneutic circle of understanding, where the previous knowledge was anticipated and reevaluated constantly by solving problems and creating solutions in a process, which finally produced the final ICT-application accessible on the BCDC website. In this process, some themes evolved and disappeared as they were solved, but the theme connected to the interaction and communication with the wider public remained in every phase. The interaction was focused on developing the right knowledge for the content of EWF and technological solution to develop the EWF. This is illustrated in Figure 3. 


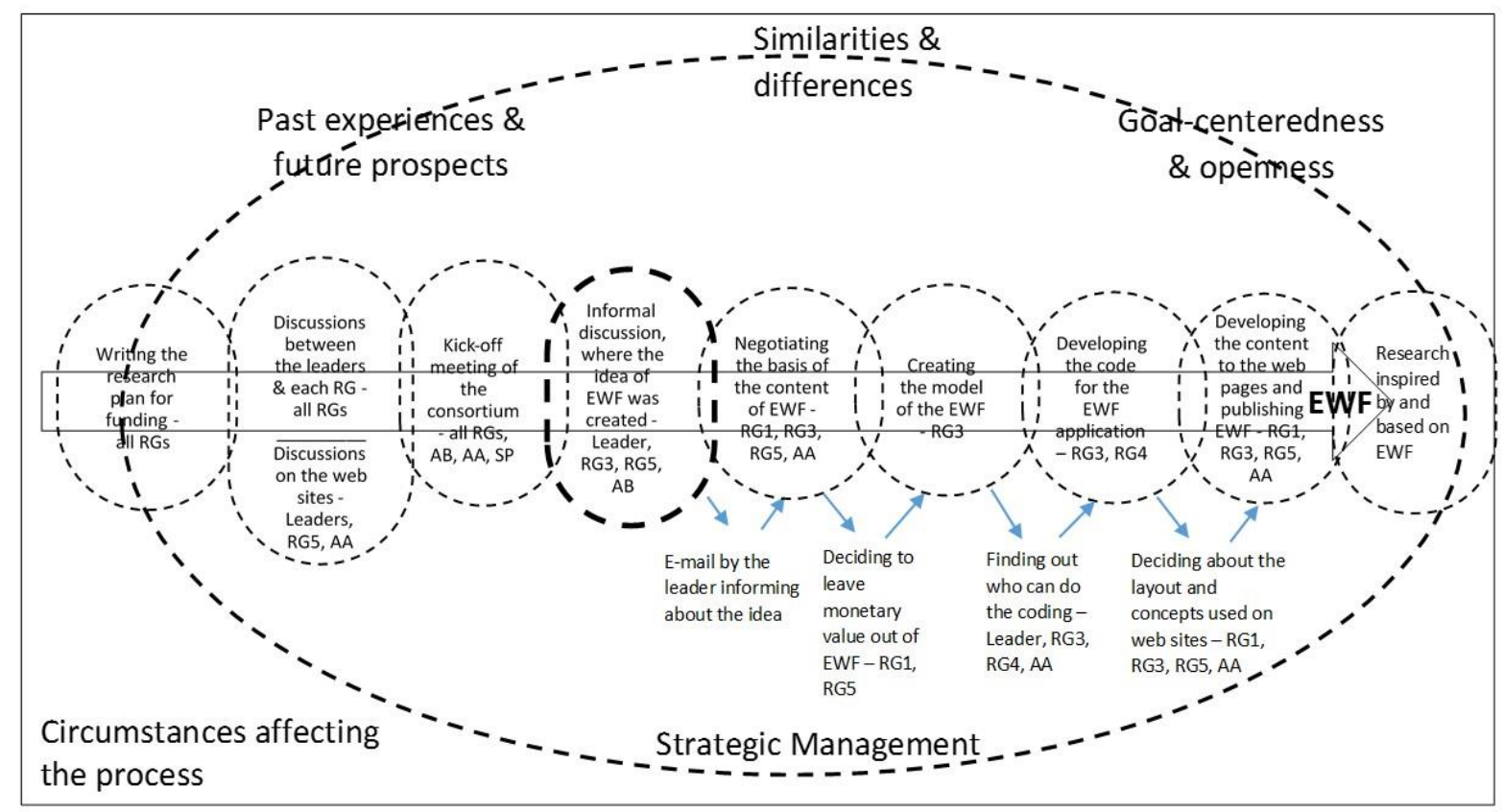

Figure 3: The knowledge creation process of the EWF examined with hermeneutic phenomenology.

Understanding temporality in phenomenological terms allowed us to understand both the eventness of the phenomenon of knowledge creation and the different temporal levels present in the interaction (Suorsa and Huotari, 2014; Suorsa, 2015). Findings indicate that enabling interaction was crucial in the development of the EWF, as the creation of the idea happened by chance in an informal interactive event organized by the community. However, its roots were in the previous knowledge of the participants and the circumstances, which promoted the creation of the idea of the EWF and its further development. Our analysis illustrates how the knowledge needed to develop the EWF evolved in a process of re-evaluating the goals by taking into account of the possibilities offered by the present moment. When analyzing this in terms of temporality, it should be noted, that plans and goals shape the being of human beings in many ways, as human beings are always intentional and heading for some conclusion (Gadamer, 1999a; Budd, 1995). With the concept of the hermeneutic circle, we can understand that heading for the future by planning and setting goals, turns out to be a manifest of the past in the present moment of interaction, and also has a tendency to limit and narrow down the possibilities, if it is not consciously reflected in the interactive events (Suorsa, 2017). However, the findings of this study illustrate, that it is important to anticipate the future so, that the process can proceed and a final product be developed, despite the problems. In addition, it should be noted, that the conception of hermeneutic circle in general can be a methodological challenge, if it is understood as a process of interpretation and meaning creation between individuals or texts (c.f. Schleiermacher, 1977; Dilthey, 1990), without acknowledging the openness of the event of interaction and the premises of hermeneutic phenomenology emphasizing the dialogical nature of human beings. Hence, our findings are related to the studies in the field of LIS, which call for the understanding of the dialogical nature of the human beings and also knowledge (Budd, 1995; Budd, 2005; Budd et al., 2010).

The hermeneutic phenomenological approach applied in this study provides us means to understand the balancing between the different, sometimes contradictory factors influencing the knowledge creation process in terms of temporality, similarities and differences, and openness and goal-centeredness. Our findings highlight, that in the context of $R \& D$, the contradiction was evident, as in research, there is a tendency to emphasize the previous knowledge, and on the other, there is a goal to discover new, also unexpected solutions. The results of this study show, that even if there was a research plan for developing 
solutions to bring together weather forecasting and knowledge on energy markets, a totally unplanned and informal discussion, where the participants could combine their knowledge, was needed to formulate how this could be done in practice. These findings are in line with the research of knowledge creation emphasizing flexibility in terms of having enough time for informal discussions in the working communities (Richtnér and Åhlström, 2010; Mitchell et al., 2009; Richtnér et al., 2014; Auernhammer and Hall, 2014). The findings also support the research of knowledge creation emphasizing the importance of finding new connections and ideas by combining ideas in a new way (Tsoukas, 2009; Topp, 2000). However, this study also shows how previous knowledge and recognition of the similarities on many levels have a decisive role in supporting the knowledge-creating process: the vast knowledge base of the scholars developed a good basis for finding new ideas, as the researchers knew what could be possible in the future. In addition, having a joint understanding of the importance of the issue, based on the scientific knowledge, enhanced the process, as the participants could discuss on a quite advanced level about the content of the EWF.

\section{Strategic management in the interactive knowledge creation process}

With our framework, we could examine this interactive process also from a structural level, as balancing between the strategic management of the knowledge process and open discussions, where the previous knowledge can be challenged and goals re-discussed. The results of this study indicate that the role of the leader of the community was essential in organizing the interaction and reassuring that the idea proceeded to action. The importance of strategic management in enhancing knowledge creation has been acknowledged in previous research (Nonaka and Toyama, 2007; Nonaka et al., 2008). Our findings illustrate, that the strategic management is manifested in practice in the action and interaction of the leader and also other active participants of the process. In addition, the strategic management was directly connected to the content of the knowledge, which could not be separated from the circumstances, such as the possibilities offered by a certain kinds of experiences of the community members and technological solutions possible. Significant for finalizing the process, were some single moments, actions or messages in the nodes of the process (see Figure 3), which led to decisions and guided to next phase. In addition, crucial was to form new goals and see possible futures beyond the EWF. This helped the community members to do compromises in developing the EWF. However, it could be stated, that the facts that the process was quite straightforward and the communication was organized by the LoC had some implications to the openness of the process, as all the members of the community could not follow the process and participate in it. For the most parts, this quite closed mode of interaction was understandable, as there was a need to keep the knowledge needed for the solution simple. However, it could be stated, that the further development of the EWF could have been faster and more creative, if the knowledge about the process had been more openly available to all. Furthermore, it could be speculated whether this way of working created a practice of interaction related to knowledge sharing and knowledge creation within the community that may challenge the more open type of interaction in the future (see Adenfelt and Lagerstrom, 2006). Hence, our study related to the studies examining knowledge sharing in working communities (Cyr and Choo, 2010; Widén-Wulff and Davenport, 2007; Ahmad \& Widén, 2015). Further studies should be conducted to understand these relations to develop practices and tools, which enable knowledge sharing more openly and flexibly during the process of knowledge creation. In addition, it would be relevant to examine the development of the working community and its evolving interaction practices in a long run (Hautala and Jauhiainen, 2014).

The findings indicate that one of the most important features in developing the original ideas to the actual solutions was the ability of the researchers to do compromises related to the scientific accuracy of the weather forecasting model. Thus, they were able to understand, that the goal of the EWF was to promote the community and to serve as the first opening of this kind, to show what combining the aspects of forecasting and energy production could mean. In addition, they also maintained the more scientific goal of accurate forecasts and investigated the phenomenon further. Furthermore, the EWF functioned as the basis for a multidisciplinary research of the Economists and the Meteorologists (Krishnamurthy et al. 2018) 
after the launch of the application. This process as a whole can be seen to have connections with organizational learning (e.g. Agryis, 1999; Rowley, 2001), a theme, which was beyond the scope of this study, but could be examined in the future to understand the development of the research community. Overall, our hermeneutic phenomenological approach, emphasizing the shared nature of knowledge creation, gives us means to understand also the strategic management as being a joint accomplishment, which is needed to find a focus of the knowledge needed in the process.

\section{Implications of the study}

This study has implications for the theoretical and methodological understanding of the knowledge creation. Altogether, this study has indicated that a phenomenological approach can be especially suitable for understanding and exploring the phenomena connected with interaction and gradual development of new knowledge. Our framework allows the examination of the experiences and the events of interaction, and is connected to the actual content of the knowledge needed and re-evaluated in the process. Hence, the findings of this study could be further elaborated to understand the life cycles of knowledge (Rowley, 2001; Evans et al., 2014) and the role of different knowledge assets (e.g. Shih-Wei and Mong-Young, 2004) in the process of creating knowledge especially in multi-organizational contexts. In addition, understanding the dialectical nature of the phenomenon of knowledge creation, which is promoted by cultivating both similarities and openness, and differences and goal-centeredness, opens up possibilities to further elaborate and examine the balance between these factors in different contexts. That should be further examined in relation to the premises of hermeneutic phenomenological tradition, which deals with the ideal of encounters between free and independent human beings, whereas in organizations various hierarchies and management also play a role in the interaction (see Wilson, 2002b; Budd et al., 2010; see also Auernhammer and Hall, 2014). This raises the question of how the openness can be obtained under the pressures of an organizational environment in a way, which promotes the creation of new and groundbreaking knowledge (see Wilson, 2002b; Cyr and Choo, 2010; see also Aggerholm and Asmuss, 2016; Aggerholm and Thomsen, 2015). With the phenomenological approach suggested in this study, this tension may open up and allow an analysis of the places of openness and criticality in organizations by recognizing the dialogical nature of humans to understand and question when encountering challenges (c.f. Budd, 1995; Budd et al., 2010; see also Suorsa and Huotari, 2014; Suorsa, 2015). Furthermore, this study could have some implications for the understanding and examining interactive knowledge and information process in the field of LIS (see e.g. Ingwersen and Jarvelin 2005, Talja et al. 2005, Hansen and Jarvelin 2005, Savolainen 2009). Especially, our findings illustrate how the phenomenon of knowledge creation is interconnected with the phenomena such as knowledge transfer, sharing and use (e.g. Widén-Wulff and Davenport, 2007). Therefore, our study contributes to the discussions concerning the relevance of the KM in the field of LIS (e.g. Wilson, 2002b; Miller, 2002).

This study has some practical implications to the developing knowledge processes, tools and circumstances to promote knowledge creation and interaction in organizations. By examining the factors influencing knowledge creation process in an unified framework can help us to understand the complex and contradictory nature of the phenomenon. This allows us to enhance knowledge creation processes in practice, as we can take into account the difficulties and challenges faced in different contexts and communities, as well as simultaneously acknowledge the possibilities and strengths of those contexts. Understanding the temporality of human beings and the factors contributing to the knowledge creation process can help to develop skills and competences of the employees, who strive to develop their ideas into practice in the complex organizational circumstances. Our findings indicate, that the possibilities of being open and reflective, but also capable of strategic management and decision making are both dependent on the organizational circumstances and conscious actions of the people involved in the knowledge creation process.

Especially, this study has some implications to the practices of organizing and conducting multidisciplinary research work in research communities. The findings relate to the notion of Perkmann et al. (2013, p. 432), 
as they state: "As funding bodies in many countries require bidding academics to provide evidence of societal impact (and not just on the academic community), understanding how engagement results in such benefits, and simultaneously maintain scientific quality, appears now of greater relevance". This study provides evidence on how a research consortium has been able to reach the societal impact without losing its scientific goals. This was possible by taking into account that there are different goals for scientific work and popularization of the science. Hence, the clear explication of the goals and setting them on different temporal levels could help in conducting both scientifically ambitious work and creating knowledge and solutions for the popularization of science. In addition, diversity of the community should be addressed in the organization of the collaborative work in the everyday life of the research community, to be able to understand what is possible and where are the limits of the different disciplines and organizations.

\section{Conclusions}

This study has illustrated how the interactive knowledge creation process can be examined and understood in terms of hermeneutic phenomenology as a continuous flux of events and experiences shaping the process. To understand the emergence of an innovation it is crucial to notice the role of the past events and experiences, as well as the expectations of the possible futures affecting the development. The understanding of the limits and possibilities provided by the circumstances is emphasized in the mediating role of the leader. In future studies, the framework suggested in this study could be further elaborated to understand these dynamics and also the limits of using the conception of hermeneutic circle in the examination of knowledge creation. This could be done by examining the relevance of discontinuity, misunderstandings and chance in the development of new knowledge. In addition, to understand the event of being together, also the phenomenology of Merleau-Ponty (2006) with the emphasis of perception and embodiment would needs to be consulted (see Küpers, 2005; c.f. Olsson, 2016; Olsson and Lloyd, 2017; Latham, 2014). Furthermore, the phenomenon of knowledge creation should be further examined by acknowledging the material environment shaping the work and interaction in organizations (Carlile et al., 2013).

Our analysis of the case of EWF explicates some key features of the phenomenon of knowledge creation in multi-organizational and multi-professional communities, working in different locations, having various goals and working practices supporting and limiting knowledge-creating interaction. The theoretical approach and chosen methods emphasize also the importance of examining these processes in a manner that takes the specific nature of the context and also the content of the issues developed into account. Thus, in the future studies the phenomena examined here should be examined in other communities. The approach developed in this study should be further elaborated to allow combining the macro and micro levels of organizational knowledge creation. In the future, it would be relevant to examine these discussions in detail both in face-to-face and computer-supported interaction (Wagner et al., 2014; Coore et al., 2014; Baralou and Tsoukas, 2015; Suorsa, 2017; see also McKenzie, 2009) to understand the dynamics of creating knowledge.

This study has limitations, related to the methods and empirical settings of the study. The findings of this study are limited, as we have concentrated on one case in a specific context. However, by analyzing one case in a detail is valuable, as it reveals the deepness of the phenomenon of knowledge creation in a manner, which would not be possible with other, more general approaches. Auto-ethnography has effects on the objectivity of the research results, as some of the authors were also key developers of the EWF. However, it was considered essential to gain knowledge on the detailed process of the developmental work and the content of the EWF. In addition, there are some limitations considering the data available of the process, as private and off-meeting interaction between the participants was not documented. Therefore, different types of data were used, to create as broad picture of the knowledge process.

\section{Acknowledgements}


This study has been funded by the Strategic Research Council, Finland, Project no 292854.

\section{References}

Adenfelt, M., Lagerstrom, K. (2006), "Enabling knowledge creation and sharing in transnational projects”, International Journal of Project Management, Vol. 24 No. 3, pp. 191-198.

Aggerholm, H.K. Asmuss, B. (2016), "A practice perspective on strategic communication”, Journal of Communication Management, Vol. 20 No. 3, pp. 195-214.

Aggerholm, H.K., Thomsen, C. (2015), "Strategic communication: the role of polyphony in management team meetings", In Holtzhausen, D. \& Zerfass, A. (eds): The Routledge Handbook of Strategic Communication. New York, NY Routledge, pp. 172-189.

Ahmad, F., Widén, G. (2015), "Language clustering and knowledge sharing in multilingual organizations: A social perspective on language", Journal of Information Science, Vol. 41 No. 4, pp. 430-443.

Alberts, D.J. (2007), “A model of multidiscipline teams in knowledge-creating organizations", Team Performance Management, Vol. 13 No. 5/6, pp. 172-183.

Anand, G., Ward, T., Tatikonda, M.V. (2010), "Role of explicit and tacit knowledge in six sigma projects: An empirical examination of differential project success", Journal of Operations Management, 28, pp. 303-315.

Angrosino, M. (2007), “Analyzing ethnographic data”, Angrosino M. (Ed.), Qualitative Research kit: Doing ethnographic and observational research, Sage Publications, London, pp. 67-76.

Argyris, C. (1999), On organizational learning, 2nd ed, Blackwell, Oxford, Blackwell.

Auernhammer, J. Hall, H. (2014), Organisational culture in knowledge creation, creativity and innovation: towards the Freiraum model”, Journal of Information Science, Vol. 40 No. 2, pp. 154-166.

Balestrin, A., Vargas, L.M., Fayard, P. (2008), "Knowledge creation in small-firm network", Journal of Knowledge Management, Vol. 12 No. 2, pp. 94-106.

Baralou, E., Tsoukas, H. (2015), "How is New Organizational Knowledge Created in a Virtual Context? An Ethnographic Study”, Organization Studies, Vol. 36 No. 5, pp. 593-620.

Belkin, N.J. (1990), “The cognitive viewpoint in information science”, Journal of Information Science, Vol. 16 No. 1, pp. 11-16.

Bligh, M.C., Pearce, C.L., Kohles, J.C. (2006), “The importance of self- and shared leadership in team based knowledge work", Journal of Managerial Psychology, Vol. 21 No. 4, pp. 296-318.

Bruce, C., Davis, K., Huges, H., Partridge, H, Stoodley, I. (2014), ’Information Experience: Contemporary Perspectives", In: Bruce, C, Davis, K, Huges, H, Partridge, H \& Stoodley, I (eds) Information Experience, Approaches to Theory and Practice. Bingley, Emerald, pp. 3-15.

Budd, J.M. (1995), "An Epistemological Foundation for Library and Information Science”, The Library Quarterly Vol. 65 No. 3: 295-318.

Budd, J.M. (2001), Knowledge and Knowing in Library and Information Science: A Philosophical Framewok. Lanham, Scarecrow Press. 
Budd, J.M. (2005), "Phenomenology and information studies", Journal of Documentation, Vol. 61 No. 1, pp. 44-59.

Budd, J.M. (2011), "Revisiting the importance of cognition in information science", Journal of Information Science, Vol. 37 No. 4, pp. 360-368.

Budd, J.M., Hill, H.,Shannon, B. (2010), "Inquiring into the Real: A Realist Phenomenological Approach", The Library Quarterly, Vol. 80 No. 3, pp. 267-284.

Burns, C., Bossaller, J. (2012), "Communication overload: a phenomenological inquiry into academic reference librarianship", Journal of Documentation, Vol. 68 No. 5, pp. 597-617.

Capurro, R., Hjørland, B. (2003), "The concept of information”, in Cronin, B. (Ed.), Annual review of information science and technology, 37, Information Today Inc, Medford, pp. 343-411.

Carlile, P.R., Nicolini, D., Langley, A., Tsoukas, H. (2013), How matter matters: Objects, artifacts, and materiality in organization studies. Oxford University Press, Oxford.

Chang, H. (2008), Autoethnography as method, Left Coast Press, Walnut Creek, California.

Choo, C.W. (2016), The inquiring organization: How organizations acquire knowledge and seek information, New York, Oxford University Press.

Chua, A. (2002), "The influence of social interaction on knowledge creation", Journal of Intellectual Capital, Vol. 3 No. 4, pp. 375-392.

Chua, A. Y. K., Kaynak, S., Foo, S. S. B. (2007), “An analysis of the delayed response to Hurricane Katrina through the lens of knowledge management.", Journal of the American Society for Information Science \& Technology, Vol. 58 No. 3, pp. 391-403.

Cook, S.N., Brown, J.S. (1999), "Bridging epistemologies: the generative dance between organizational knowledge and organizational knowing”, Organization Science, Vol. 10 No. 4, pp. 382-400.

Cooren, F., Vaara, E., Langley, A., Tsoukas, H. (2014), "Language and Communication at Work:

Discourse, Narrativity, and Organizing: Introducing the Fourth Volume of Perspectives on Process Organization Studies" in Cooren, F., Vaar, E., Langley, A., Tsoukas, H., (Eds.), Language and Communication at Work: Discourse, Narrativity, and Organizing, Oxford University Press, Oxford, pp. $1-16$.

Cornelius, I. (1996), Meaning and Method in Information Studies. Norwood, NJ, Ablex.

Cross, R., Parker, A., Prusak, L., Stephen, P.B. (2001), "Knowing what we know: Supporting knowledge creation and sharing in social networks", Organizational Dynamics, Vol. 30 No. 2, pp. 100-120.

Cyr, S., Choo, C.W. (2010), The individual and social dynamics of knowledge sharing: An exploratory study. Journal of Documentation, Vol. 66 No. 6, pp. 824-846.

Dalbello, M. (2005a), "A phenomenological study of an emergent National Digital Library, Part I: Theory and methodological framework”, Library Quarterly, Vol. 75 No. 4, pp. 391-420.

Dalbello, M. (2005b), "A phenomenological study of an emergent national digital library, Part II: The narratives of development", Library Quarterly, Vol. 75 No. 4: e28-e70. 
Dalkir, K. (2011). Knowledge management in theory and practice. Second edition. Cambridge (Mass.), MIT Press.

Davenport, E. (2001), "Knowledge management issues for online organisations: 'communities of practice' as an exploratory framework", Journal of Documentation, Vol. 57 No. 1, pp.61-75.

Day, R.E. (2011), "Death of the user: reconceptualizing subjects, objects, and their relations", Journal of the American Society for Information Science and Technology, Vol. 62 No. 1, pp. 78-88.

Demircioglu, M.A., Audretsch, D.B. (2017), "Conditions for innovation in public sector organizations", Research Policy, 46, pp. 1681-1691.

Dilthey, W. (1990), Gesammelte Schriften, I Band: Einleitung in die Geisteswissenschaften, 9. Auflage. Stuttgart: BG Teubner Verlagsgesellschaft und Göttingen: Vandenhoeck \& Ruprecht.

Eisenhardt, K.M. (1989), "Building theories from case study research", Academy of Management Review Vol. 14 No. 4, pp. 532-550.

Eliufoo, H. (2008), "Knowledge creation in construction organizations: a case approach", The Learning Organization, Vol. 15 No. 4, pp. 309-325.

Evans, M.M., Dalkir, K., Bidian, C. (2014), “A Holistic View of the Knowledge Life Cycle: The Knowledge Management Cycle (KMC) Model”, The Electronic Journal of Knowledge Management, Vol. 12 No. 2, pp. 85-97.

Gadamer, H.-G. (1999a), Wahrheit und Methode, in, Gesammelte Werke 1: Hermeneutik I, JCB Mohr, Tübingen, pp. 1-494.

Gadamer. H.-G. (1999b), "Die Aktualität des Schönen. Kunst als Spiel, Symbol und Fest”, in, Gesammelte Werke 8: Ästhetik und Poetik 1: Kunst als Aussage, JCB Mohr, Tübingen, pp. 34-143.

Gorichanaz, T. (2015), "Information on the run: experiencing information during an ultramarathon", Information Research, Vol. 20 No. 4, paper 697. Retrieved from http://InformationRnet/ir/20 4/paper697.html.

Gourlay, S. (2006), “Conceptualizing knowledge creation: A critique of Nonaka's theory”, Journal of Management Studies, 43, pp. 1415-1436.

Hall, H. (2001), "Input-friendliness: motivating knowledge sharing across intranets", Journal of Information Science, Vol. 27, No. 3, pp. 139-146.

Hansen, P., Jarvelin, K. (2005), Collaborative information retrieval in an information-intensive domain. Information Processing \& Management, Vol. 41 No. 5, pp. 1101-1119.

Hautala, J., Jauhiainen, J. (2014), "Spatio-temporal processes of knowledge creation”, Research Policy, Vol. 43 No. 4, pp. 655-668.

Heidegger, M. (1985), Being and time, Blackwell, Oxford.

Heinrichs, J.H., Lim, J-S. (2005), "Model for Organizational Knowledge Creation and Strategic Use of Information", Journal of the American Society for Information Science \& Technology, Vol. 56 No. 6, pp. 620-629. 
Herman, H.M.T., Mitchell, R.J. (2010), “A theoretical model for transformational leadership and knowledge creation: the role of open-mindedness norms and leader-member exchange", Journal of Management and Organization, Vol. 16 No. 1, pp. 38-99.

Hjørland, B. (2004), “Arguments for Philosophical Realism in Library and Information Science”, Library Trends, Vol. 52 No. 3, pp. 488-506.

Hong, J., Heikkinen, J., Blomqvist, K. (2010), "Culture and knowledge co-creation in R\&D collaboration between MNCs and Chinese universities", Knowledge and Process Management, Vol. 17 No. 12, pp. 6273.

Hultgren, F. (2013), “The stranger's tale: information seeking as an outsider activity", Journal of Documentation, Vol. 69 No. 2, pp. 275-294.

Huotari, M.-L., Iivonen, M. (2004), “Managing knowledge-based organizations through trust”. In: Huotari, M.-L. \& Iivonen, M. (eds) Trust in Knowledge Management and Systems in Organizations. Hershey, PA, Idea Group Publishing: 1-29.

Husserl, E. (1981), Philosophie als strenge Wissenschaft. Frankfurt am Main, Klostermann.

Ingwersen, P, (1982), "Search procedures in the library - analysed from the cognitive point of view", Journal of documentation, Vol. 38 No. 3, pp. 165-191.

Ingwersen, P., Järvelin, K. (2005), The turn: Integration of information seeking and retrieval in context. Dordrecht, Springer/Kluwer.

Jashapara, A. (2004), Knowledge Management: An Integrated Approach, FT Prentice-Hall, Harlow.

Jashapara, A. (2005), "The emerging discourse of knowledge management: a new dawn for information science research?”, Journal of Information Science, Vol. 31, No. 2, pp. 136-148.

Jashapara, A. (2007), "Moving beyond tacit and explicit distinctions: a realist theory of organizational knowledge", Journal of Information Science, Vol. 33 No. 6, pp. 752-766.

Kodama, M. (2005), "Knowledge Creation through Networked Strategic Communities - Case Studies on New Product Development in Japanese Companies", Long Range Planning, 38, pp. 27-49.

Krishnamurthy, C.K.B., Vesterberg, M., Böök, H., Lindfors, A., Svento, R. (2018), "Benefits of real-time pricing and rooftop solar PV generation: Explorations using Swedish micro-data" Scandinavian Working papers for Economics. Retrieved in March 2018 in https://swopec.hhs.se/slucer/abs/slucer2018_004.htm.

Küpers, W. (2005), "Phenomenology of embodied implicit and narrative knowing”, Journal of Knowledge Management, Vol. 9 No. 6, pp. 114-133.

Känsäkoski, H. (2017), "Information and knowledge processes as a knowledge management framework in health care: Towards shared decision making?", Journal of Documentation, Vol. 73 Issue: 4, pp.748766.

Latham, K.F. (2014), Experiencing documents. Journal of Documentation, Vol. 70 No. 4, pp. 544-561.

Latham, K.F. (2015), What is the real thing in the museum? An interpretative phenomenological study. Museum Management and Curatorship, Vol. 30 No. 1, pp. 2-20. 
Laverty, S. (2003), "Hermeneutic Phenomenology and Phenomenology: A Comparison of Historical and Methodological Considerations", International Journal of Qualitative Methods, Vol. 2 No. 3, pp. 21-35.

Lopez, K.A., Willis, D.G. (2004), "Descriptive versus interpretive phenomenology: their contributions to nursing knowledge", Qualitative Health Research, Vol. 14 No. 5, pp. 726-735.

Martín-de-Castro, G., López-Sáez, P., Navas-López, J.E. (2008), "Processes of knowledge creation in knowledge-intensive firms: Empirical evidence from Boston's Route 128 and Spain”, Technovation, 28, pp. 222-230.

Maso, I. (2001), "Phenomenology and ethnography", in Atkinson, P., Coffey, A., Delamont, S., Lofland, J., Lofland, L., (Eds.), Handbook of Ethnography, Sage Publications, London, pp. 136-144.

McInerney, C.R. (2002), "Knowledge management and the dynamic nature of knowledge", Journal of the American Society for Information Science and Technology, Vol. 53 No. 12, pp. 1009-1018.

McKenzie, P.J. (2009), "Informing Choice: The Organization of Institutional Interaction in Clinical Midwifery Care”, Library \& Information Science Research, Vol. 31 No. 3, pp. 163-173.

Mengis, J., Eppler, M. (2008), "Understanding and managing conversations from a knowledge perspective: an analysis of the roles and rules of face-to-face conversations in organizations", Organization Studies, Vol. 29 No. 10, pp. 1287-1313.

Merleau-Ponty, M. (2006), Phenomenology of Perception, Routledge, London and New York.

Migdadi, M.M. (2009), “A knowledge-centered culture as an antecedent of effective knowledge management at information technology centers in the Jordanian universities", Journal of Systems and Information Technology, Vol. 11 No. 2, pp. 89-116.

Miller, F. (2002), 'I = 0 (Information has no intrinsic meaning)", Information Research, Vol. 8 No. 1, paper 140. [Available at http://InformationR.net/ir/8-1/paper140.html]

Mitchell, R., Nicholas, S., Boyle, B. (2009), "The Role of Openness to Cognitive Diversity and Group Processes in Knowledge Creation”, Small Group Research, Vol. 40 No. 5, pp. 535-554.

Moran, D. (2002), “Editor's Introduction”. In: Moran, D \& Mooney, T (eds) Phenomenology Reader. London and New York, Routledge, pp. 1-26.

Morner, M., von Krogh, G. (2009), “A note on knowledge creation in open-source software projects: what can we learn from Luhmann's theory of social systems?" Systemic Practice and Action Research, Vol. 22 No. 6, pp. 431-443.

Moustakas, C.E. (1994), Phenomenological research methods, Sage Publications, Thousand Oaks, California \& London.

Nonaka, I. (1994), “A dynamic theory of knowledge creation”, Organization Science, 5, pp. 14-37.

Nonaka, I., Takeuchi, H. (1995), The knowledge-creating company, Oxford University Press, Oxford.

Nonaka, I. Toyama, R. (2007), "Strategic management as distributed practical wisdom (phronesis)", Industrial and Corporate Change, Vol. 16 No. 3, pp. 371-394. 
Nonaka, I., Toyama, R., Hirata, T. (2008), Managing Flow. A Process Theory of the Knowledge-Based Firm. Hampshire and New York, Palgrave Macmillan.

O'Farrill, R.T. (2010), 'Information literacy and knowledge management at work: Conceptions of effective information use at NHS24", Journal of Documentation, Vol. 66 No. 5, pp. 706-733.

Olsen, D.S. (2009), “Emerging interdisclipinary practice: making nanoreactors” The Learning Organization, Vol. 16 No. 5, pp. 398-408.

Olsson, M. (2016) "Making sense of the past: The embodied information practices of field archaeologists", Journal of Information Science, Vol. 42 No. 3, pp. 410-419.

Olsson, M., Lloyd, A. (2017), "Being in place: embodied information practices", Information Research, Vol. 22 No. 1, CoLIS paper 1601. Retrieved from http://InformationR.net/ir/22-1/colis/colis1601.html

Orlikowski. W.J. (2002), "Knowing in practice: Enacting a collective capability in distributed organizing”, Organization Science, Vol. 13 No. 3, pp. 249-273.

Orzano, A.J., McInerney, C.R., Scharf, D., Tallia, A.F., Crabtree, B.F. (2008), ”A knowledge management model: Implications for enhancing quality in health care." Journal of the American Society for Information Science and Technology, Vol. 59 No. 3, pp. 489-505.

Perkmann, M., Tartari, V., McKelvey, M., Autio, E., Brostrom, A., D’Este, P., Fini, A., Grimaldi, R., Hughes, A., Krabel, M.K., Llerena, P., Lissoni, F., Salter, A., Sobrero, M. (2013), “Academic engagement and commercialisation: A review of the literature on university-industry relations", Research Policy, 42, pp. 423-442.

Popadiuk, S., Choo, C.W. (2006), "Innovation and knowledge creation: how are these concepts related?"،, International Journal of Information Management, Vol. 26 No. 4, pp. 302-312.

Ragsdell, G. (2009), "Participatory action research: A winning strategy for KM.” Journal of Knowledge Management, Vol. 13 No. 6, pp. 564-576.

Ramírez, A.M., Morales, V.J.G., Aranda, D.A. (2012), "Knowledge creation and flexibility of distribution of information", Industrial Management + Data Systems, Vol. 112 No. 2, pp. 166-185.

Richtnér, A., Åhlström, P. (2010), “Top management control and knowledge creation in new product development", International Journal of Operations \& Production Management, Vol. 30 No. 10, pp. 1006-1031.

Richtnér, A., Åhlström, P., Goffin, K. (2014), "Squeezing R\&D: A Study of Organizational Slack and Knowledge Creation in NPD, Using the SECI Model", The Journal of Product Innovation Management, Vol. 31 No. 6, pp. 1268-1290.

Robson, A, Robinson, L. (2013), "Building on models of information behaviour: linking information seeking and communication." Journal of Documentation, Vol. 69 No. 2, pp. 169-193.

Rowley, J. (2001), "Knowledge management in pursuit of learning: the Learning with Knowledge Cycle", Journal of Information Science, Vol. 27, No. 4, pp. 227-237.

Savolainen, R. (2007), "Information source horizons and source preferences of environmental activists: A social phenomenological approach", Journal of the American Society for Information Science and Technology, Vol. 58 No. 12, pp. 1709-1719. 
Savolainen, R. (2008), Everyday information practices: A social phenomenological perspective, Scarecrow Press, Lanham, MD.

Savolainen, R. (2009), "Information use and information processing”, Journal of Documentation, Vol. 65 No. 2, pp. 187-207.

Scandura, A. (2016), "University industry collaboration and firms R\&D effort", Research Policy, 45, pp. 1907-1922.

Schleiermacher, F.D.E. (1977), Hermeneutik und Kritik: Mit einem Anhang sprachphilosophischer Texte Schleiermachers, Frankfurt am Main, Suhrkamp.

Schreier, M. (2012), "Qualitative content analysis", in Flick, U. (Ed.), The SAGE Handbook of Qualitative Data Analysis, Sage Publications, Thousand Oaks, CA, pp. 170-183.

Shih-Wei, C., \& Mong-Young, H. (2004). Knowledge management: The distinctive roles of knowledge assets in facilitating knowledge creation. Journal of Information Science, Vol. 30 No. 2, pp. 146-164.

Smith, V. (2001), "Ethnographies of Work and the Work of Ethnographers", in Atkinson, P., Coffey, A., Delamont, S., Lofland, J., Lofland, L. (Eds.), Handbook of Ethnography, Sage, London, pp. 220-233.

Strauss, A., Corbin, J. (1990), Basics of Qualitative Research. Grounded Theory Procedures and Techniques, Sage Publications, Newbury Park, California.

Suorsa, A., Huotari, M.-L. (2014), "Knowledge creation and the concept of human being - a phenomenological approach", Journal of the American Society for Information Science and Technology, Vol. 65 No. 5, pp. 1042-1067.

Suorsa, A. (2015), "Knowledge creation and play - a phenomenological approach", Journal of Documentation, Vol. 71 No. 3, pp. 503-525.

Suorsa, A. (2017), "Knowledge creation and play - A phenomenological study within a multi-professional and multi-organizational community", Journal of Documentation, Vol. 73 No. 6, pp. 1167-1191.

Taalbi, J. (2017), "What drives innovation? Evidence from economic history", Research Policy, 46, pp. $1437-1453$.

Talja, S., Tuominen, K., Savolainen, R. (2005), ’Isms in information science: constructivism, collectivism and constructionism", Journal of Documentation, Vol. 61 No. 1, pp. 79-101.

Tietz, U. (2000), Hans-Georg Gadamer zur Einführung, Junius Verlag Gmbh, Hamburg.

Topp, W. (2000), “Generative conversations: Applying Lyotard's discourse model to knowledge creation within contemporary organizations", Systems Research and Behavioral Science, Vol. 17 No. 4, pp. 333340.

Tsoukas, H. (2009), "A Dialogical Approach to the Creation of New Knowledge in Organizations”, Organization Science, Vol. 20 No. 6, pp. 941-957.

Vakkari, P. (2008), "Trends and approaches in information behaviour research", Information Research, Vol. 13 No. 4, paper 361. [Available at http://InformationR.net/ir/13-4/paper361.html]. 
van Helden, J., Aardema, H., ter Bogt, H.J., Groot, T.L.C.M. (2010), "Knowledge creation for practice in public sector management accounting by consultants and academics", Management Account Research, 21, pp. 83-94.

Värlander, S. (2008), "The Role of Situated Embodied Interaction in the Banking Customer Knowledge Creation Process" International Journal of Knowledge Management, Vol. 4 No. 4, pp. 62-76.

Verdonschot, S. (2006), "Methods to enhance reflective behaviour in innovative processes", Journal of Industrial Training, Vol. 30 No 9, pp. 670-686.

Wagner, D., Vollmar, G., Wagner, H. (2014), "The impact of information technology on knowledge creation: An affordance approach to social media", Journal of Enterprise Information Management, Vol. 27 No. 1, pp. 31-44.

Wang, J., \& Guan, J. (2005), "The analysis and evaluation of knowledge efficiency in research groups." Journal of the American Society for Information Science and Technology, Vol. 56 No. 11, pp. 1217-1226.

Widén-Wulff, G., \& Ginman, M. (2004). "Explaining knowledge sharing in organizations through the dimensions of social capital." Journal of Information Science, Vol. 30 No. 5, pp. 448-458.

Widén-Wulff, G. \& Davenport, E. (2007), "Activity systems, information sharing and the development of organizational knowledge in two Finnish firms: an exploratory study using Activity Theory". Information Research, Vol. 12 No. 3, paper 310. [Available at http://InformationR.net/ir/12-3/paper310.html]

Wilson, T.D. (2002a), "Alfred Schutz, phenomenology and research methodology for information behaviour research", The New Review of Information Behaviour Research 3: 71-81.

Wilson, T.D. (2002b), "The nonsense of 'knowledge management"”, Information Research 8(1), paper 144. [Available at http://InformationR.net/ir/8-1/paper144.html]

Yates-Mercer, P., Bawden, D. (2002), "Managing the paradox: The valuation of knowledge and knowledge management." Journal of Information Science 28(1): 19-29.

Yin, R.K. (2009), Case study research: design and methods, 4th ed, Sage Publications, Thousand Oaks.

Zanzouri, C., Francois, J.-C. (2013), "Knowledge management practices within a collaborative R\&D project: Case study of a firm in a cluster of railway industry", Business Process Management Journal, Vol. 19 No. 5, pp. 819-840. 